\title{
Learning from Nature: Bacterial Spores as a Target for Current Technologies in Medicine (Review)
}

DOI: $10.17691 / \mathrm{stm} 2020.12 .3 .13$

Received September 14, 2019

B.G. Andryukov, MD, DSc, Leading Researcher, Laboratory of Molecular Microbiology ${ }^{1}$; Professor,

Department of Fundamental Sciences;

A.A. Karpenko, PhD, Senior Researcher, Laboratory of Cell Biophysics;

I.N. Lyapun, PhD, Researcher, Laboratory of Molecular Microbiology ${ }^{1}$

${ }^{1}$ G.P. Somov Institute of Epidemiology and Microbiology, 1 Selskaya St., Vladivostok, 690087, Russia;

${ }^{2}$ Far Eastern Federal University, 10 Village Ayaks, Island Russkiy, Vladivostok, 690922, Russia;

${ }^{3}$ A.V. Zhirmunsky National Scientific Center of Marine Biology, Far Eastern Branch

of the Russian Academy of Sciences, 17 Palchevskogo St., Vladivostok, 690041, Russia

The capability of some representatives of Clostridium spp. and Bacillus spp. genera to form spores in extreme external conditions long ago became a subject of medico-biological investigations. Bacterial spores represent dormant cellular forms of gram-positive bacteria possessing a high potential of stability and the capability to endure extreme conditions of their habitat. Owing to these properties, bacterial spores are recognized as the most stable systems on the planet, and spore-forming microorganisms became widely spread in various ecosystems.

Spore-forming bacteria have been attracted increased interest for years due to their epidemiological danger. Bacterial spores may be in the quiescent state for dozens or hundreds of years but after they appear in the favorable conditions of a human or animal organism, they turn into vegetative forms causing an infectious process. The greatest threat among the pathogenic spore-forming bacteria is posed by the causative agents of anthrax (B. anthracis), food toxicoinfection (B. cereus), pseudomembranous colitis (C. difficile), botulism (C. botulinum), gas gangrene (C. perfringens).

For the effective prevention of severe infectious diseases first of all it is necessary to study the molecular structure of bacterial spores and the biochemical mechanisms of sporulation and to develop innovative methods of detection and disinfection of dormant cells. There is another side of the problem: the necessity to investigate exo- and endospores from the standpoint of obtaining similar artificially synthesized models in order to use them in the latest medical technologies for the development of thermostable vaccines, delivery of biologically active substances to the tissues and intracellular structures. In recent years, bacterial spores have become an interesting object for the exploration from the point of view of a new paradigm of unicellular microbiology in order to study microbial heterogeneity by means of the modern analytical tools.

Key words: bacterial spores; biotechnologies; sporulation; exospores; endospores; atomic-force microscopy; Raman spectroscopy; plasma chemical techniques.

\section{Introduction}

Bacteria are divided into gram-positive and gramnegative depending on the presence of the outer membrane and thickness of the peptidoglycan layer. Under unfavorable environmental conditions, some gram-positive bacteria realize their capability of forming spores. These spherical or slightly elongated dense structures are extremely resistant to the physical and chemical factors of the environment and are recognized as the most stable form of life on the planet $[1,2]$. Since spores are formed inside the mother cell (sporangia), they are called endospores. The capability of the pathogenic microorganisms to form endospores accounts for their wide spread. In some cases, the spores of a disease causative agent are able to be independent infectious pathogens $[1,3,4]$.
For example, spores of the anthrax causative agent Bacillus anthracis can survive in soil for decades preserving potential epizootic and epidemiological danger but having appeared on the surface they may become a source of contamination for humans and animals. For this reason, anthrax burial sites maintain the status of restricted access areas for a long time [2, 4]. Of special concern is the possibility of $B$. anthracis spores to be one of the most probable agents of bioterrorism [4-6]. A tragic incident of intentional dissemination of anthrax spores happened in the USA in 2001 (spores were mailed in the powder form in envelopes) demonstrated an evident easiness for the spores of these dangerous pathogen to become the cause of infectious disease outbreak $[3,5,7]$.

Investigations of the outer architectonics and

Corresponding author: Boris G. Andryukov, e-mail: andrukov_bg@mail.ru 
morphological spore structure in various spore-forming bacteria have revealed some specific features [2, 4, 6]. According to the structure, endospores are divided into two categories: those enveloped in a dense outer coat, exosporium, and those without it. For instance, soil bacteria Bacillus subtilis are the most studied example of spore formation producing no exosporium [3, 5, 7]. Though enough knowledge about the structure and function of endospores have been accumulated by microbiologists during decades, quite a number of questions in relation to exospores remain unanswered until now [5, 6-8].

The majority of data about molecular mechanisms of formation of spores and their functions in sporeforming gram-positive bacteria were studied and well described on the strains of Bacillus spp. and Clostridium spp. using mainly molecular genetic methods and transmission electron microscopy $[3,5,8]$. For example, for many years isolates of $B$. subtilis have been and remain one of the most common models for the study of genetic regulation and biochemical structural organization of the bacterial spores [3, 6, 9]. Additionally to the already mentioned $B$. anthracis, special attention among pathogenic spore-forming bacteria is attracted by Bacillus cereus causing toxicoinfections and the representatives of the Clostridium spp. genus: C. botulinum (causative agent of botulism), C. perfringens (etiological agent of gas gangrene), and C. difficile (the most frequent source of nosocomial infections in the world) [8-11].

The urgent character of studying the structure and spatial organization of these dormant bacterial forms by means of the current analytical technologies of molecular biology is connected primarily with their epidemiological significance.

Highly sensitive and rapid diagnostic technologies for bacterial spore detection are presently being searched for which is a burning problem for medical diagnosis, epidemiology, and for the solution of biosafety tasks as well. Besides, unsolved are the questions of effective sterilization of medical equipment and healthcare products which is important for prevention of nosocomial infections caused by pathogenic spore-forming agents $[3,6,7]$.

The other perspective innovative biotechnological direction is an attempt to copy artificially the architectonics of bacterial spores to impart similar stability to the model analog systems which may find a wide scientific and practical application in pharmacology, medicine, ecology, agriculture, and other branches [8, 12].

In the present review, the results of studying molecular mechanisms of bacterial spore stability using modern analytical tools have been assessed, the directions of the application of acquired knowledge in the current technologies have been also defined.

The sources were searched using the Cochrane Library resources (Wiley Online Library directory),
EMBASE (EMBASE.com), PubMed, PubMed Central, EMBASE and MEDLINE integrated on the platform Elsevier, CINAHL, Web of Science Core Collection (Science Citation Index Expanded). The sampling strategy was determined by the retrieval of the scientific papers contained in the subject directories. The depth of search covered 2003-2019 years.

\section{Endospores and molecular mechanisms of their stability}

Sporulation in gram-positive bacteria. Early classifications of bacteria were based on their capability to sporulation [13]. Spore formation in bacteria was developed as a defense mechanism increasing considerably the capacity to survive in the environment. Bacterial spores can withstand unfavorable external factors such as high or low temperatures, absence of a nutrient substrate, the effect of antibacterial drugs and disinfectants, radiation, high pressure, ultraviolet radiation [14-17].

A stepwise process of spore formation is rather complicated, represents a successive genetic regulation of the synthesis of numerous specific proteins accompanied by cellular differentiation and taking about $8 \mathrm{~h}[15,18,19]$. The outcome of sporulation is formation of mature, metabolically quiescent and reproductively inactive endospore which morphologically and structurally differs radically from the mother cell [20-22].

Molecular genetic regulation of spore formation. Sporulation is a genetically determined process of forming a spore inside a vegetative mother cell which is in the stationary phase of its life cycle. Exposure to stress factors triggers the genetic mechanisms providing the synthesis of transcription factors. They are responsible for bioregulation and succession of morphofunctional changes which ultimately result in the transformation of the vegetative form into a spore [11, 23-26].

Regulation of spore formation and the sophisticated molecular genetic systems providing this process were disclosed, to a large extent, only at the beginning of the XXI century [13, 27-29]. Absence of the nutrient substrate is a triggering factor of sporulation. Under these conditions, activation of gene spoOA encoding the similarly-named protein molecule takes place [19, 30, 31]. As a result of phosphorylation reaction, the protein Spo0A is transformed into the active form SpoOA P and causes expression of numerous genes (about 200) including sigH, spollE, ftsZ, and others. All these genes encode protein synthesis providing a successive running of seven sporulation stages (Figure 1). Gene $\mathrm{sigH}$, in particular, modulates synthesis of the protein transcription $\sigma$-subunits $(\sigma \mathrm{H}, \sigma \mathrm{F})$ regulating the correct staging of spore formation [31-33]. This regulation pattern gives definite signals of gene expression in the mother cell and the frontal part of the spore which controls the sporulation (it requires several hours to complete) and turns on activation of a set of alternative 


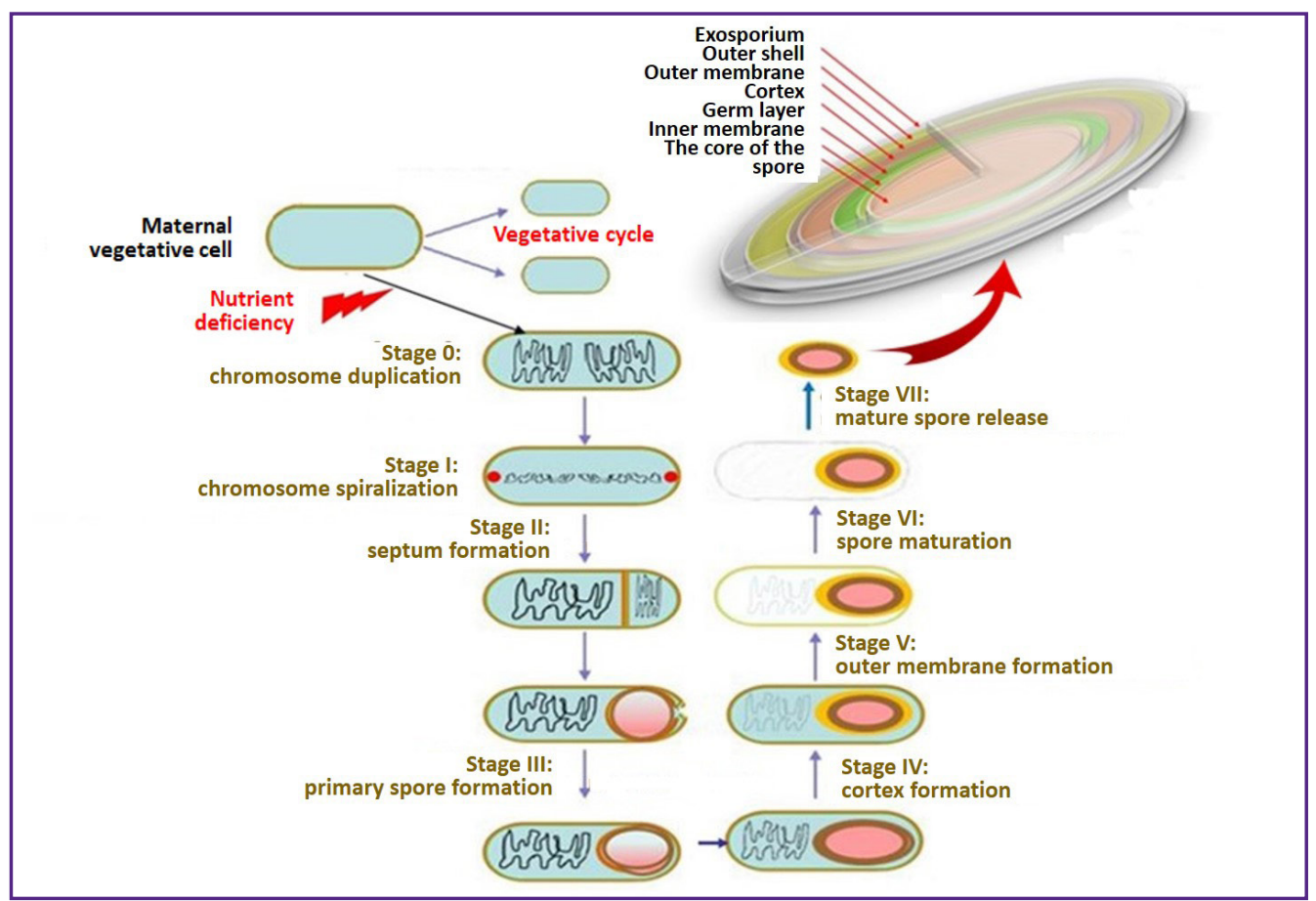

Figure 1. Succession of morphologic changes at different stages of sporulation in grampositive bacteria (drawing courtesy of the authors)

$\sigma$-factors. These factors impart unidirectionality to the cascade culminating in endospore formation [29, 34].

As a result, the cell undergoes a very complicated, precisely definite succession of morphological and biochemical events which eventually lead to the formation of mature endospores. A special protein forces one full copy of DNA into a future prospore utilizing the ATP energy, and the division is terminated. Once the spore formation is completed, the mother cell is subjected to the programmed autolysis releasing the mature spore to the environment [35].

Molecular mechanisms of spore thermal stability. Thermal stability is of key significance for endospore preservation distinguishing them from vegetative cells. The mechanisms of endospore heat resistance are very complicated and are not yet studied to the full extent [15, 22, 36, 37].

As a rule, thermal sterilization is a method of choice to provide reliable sterilization. However, investigations conducted by Scheldeman et al. [38] and Schubert et al. [39] have shown that endospores are capable to survive after the standard thermal sterilization methods and special modes of thermal treatment are necessary for their elimination.

The basis of tolerance to high temperatures is known to be dehydration of the dormant cell $[15,37]$. The result of sporulation is formation of endospores being in the state of reproductive and metabolic quiescence, reduced enzymatic activity, and content of high energy compounds (ATP and NADH). Several additional coatings in contrast to a common vegetative cell serve as a barrier against penetration of water substances dissolved in it. Dehydration preserves the proteins within the spore from denaturation at extremely high temperatures and irreversible aggregation which mediates the capacity of the spores to survive for a long time (decades, hundreds, and more years) without any nutrient resources under the conditions fatal for the vegetative cells [22, 36, 37, 40].

Two variants of equipment and instrument sterilization are conventionally employed in medical facilities. The first method uses steam. The objects are treated with steam heated to $110^{\circ} \mathrm{C}$ for $20 \mathrm{~min}$. In the second variant, items are kept in a dry-air sterilizer at $120^{\circ} \mathrm{C}$ or higher not less than $45 \mathrm{~min}$. Nevertheless, the mentioned works $[38,39]$ demonstrate insufficient effectivity of the thermal processing methods as some endospores are able to survive. For instance, it takes $3 \mathrm{~h}$ to kill spores with dry heat at $110^{\circ} \mathrm{C}$ and $1 \mathrm{~h}$ at $140^{\circ} \mathrm{C}$. The researchers believe that more effective methods of sterilization are necessary to eliminate the dormant bacterial forms completely.

Endospores are dehydrated with dipicolinic (pyridine2,6-dicarboxylic) acid (DPA) which forms a chelate complex with calcium and other bivalent cations and decreases water content in the spores to a very low level $[7,15,22,37,41,42]$. DPA makes up $5-15 \%$ of the total endospore mass and is not found in the vegetative cells $[15,40,43,44]$ (Figure 2).

The role of DPA in a bacterial cell has not been completely understood until now though this substance 


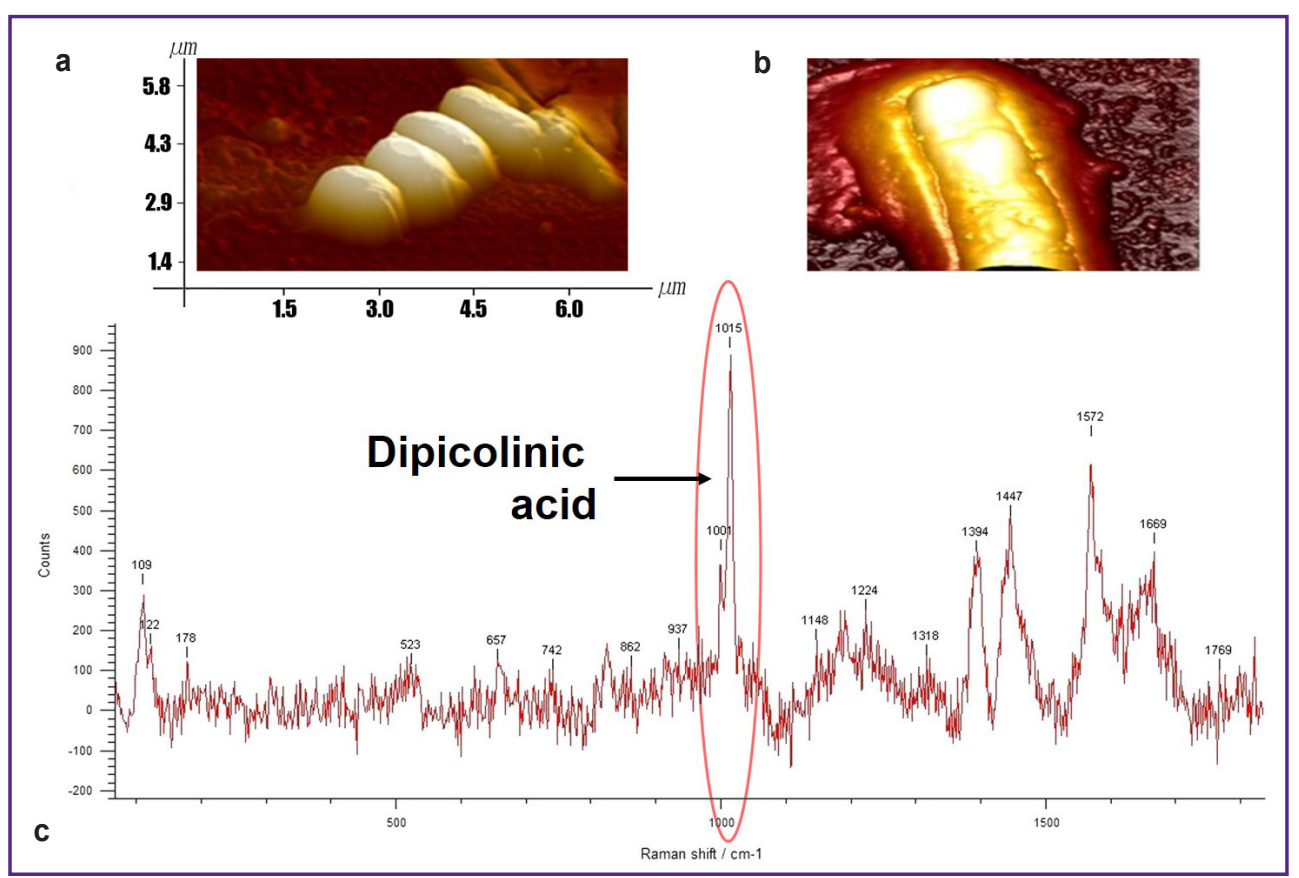

Figure 2. Visualization and Raman spectroscopy of the spores:

(a), (b) B. subtilis endospores (atomic-force microscopy); (c) Raman spectrum of B. subtili endospore and "dipicolinic acid" biomarker (photo and drawing courtesy of the authors)

was detected long ago and since that time has been actively studied [22, 41, 42, 44]. In addition to the key role in providing the cell dehydration [36], DPA participates actively in maintaining the metabolically inactive state [7] and stabilization of intracellular proteins $[7,36,37,41]$. In this case, the cell appears to be reliably protected against extreme thermal effect since the processes of denaturation, aggregation, and lysis occur in the period prior to vegetative growth $[43,44]$.

Driks [45] and Setlow [29] believe that inclusion of DPA in the structure of the molecular DNA and RNA promotes formation of a gel-like polymer matrix and the stability of nucleic acids increases under the conditions of hyperthermia.

When external conditions become favorable, spore germination and generation of the vegetative bacterial forms are initiated. The DPA in this case is released to the external environment while water enters the cell triggering metabolic reactions [22, 36].

The unique properties of DPA endospores allowed modern biotechnologists to consider it as a perspective filling (excipient) for enhancing the stability of liquid biopharmaceutical highly concentrated protein preparations (e.g., antibodies) to improve their efficacy and to prevent nonspecific aggregation [37]. Besides, in recent years, DPA is considered to be a unique and reliable marker of bacterial endospores and therefore is of great interest to the designers of colorimetric and fluorometric diagnostic systems [22, 41]. Presently, the method of combination scattering (coherent Raman spectroscopy) is becoming more and more popular for reliable, prompt, and unambiguous on-line identification of this molecular marker [22, 43, 46-49].

Molecular structure and morphology of endospores. Formation of the structurally complicated cellular wall goes on still at the stage of a primordium (prospore) inside the mother cell. The inner coat of the daughter cell is peptidoglycan which later, after the spore germination, becomes the basic cellular wall. A cortex is built over it being an additional layer of peptidoglycan which is a bit different in its composition from the inner layer $[13,23,25,50]$. In particular, there are modified lateral peptide and muramiko- $\delta$-lactam crosslinks between glycan chains $[15,41,51,52]$.

Tight protein coats are formed outside and the number of them varies in different bacterial species. The study of the chemical structure of the spore outer coat, exosporium, has been difficult for a long time due to a tight cross-linking of the protein molecules. It is owing to these strong links that a dormant form acquires stability to hydrolases and other aggressive external factors. After the introduction of mass spectroscopy, presence of 70 various proteins has been established in the outer coat $[51,53,54]$.

All mentioned structures are characterized by low permeability for water and other inorganic and organic molecules. Due to the specific assembly and special arrangement of the coat molecules, endospores can maintain viability for a long time waiting for the favorable environmental conditions to germinate $[7,15,55,56]$. 
The spore protoplast is represented by dehydrated cytoplasm harboring the chromosome material and protein synthesizing systems. The chemical protoplasm structure contains nucleic acids, dipicolinates, ions of magnesium, calcium, manganese, and SAPSs (small acid-soluble proteins). Their molecular mass is below $12 \mathrm{kDa}$, SAPSs making up $20 \%$ of all spore proteins $[20,22,34,36]$. Acid-resistant proteins perform primarily a protective function preventing a destructive effect of ultraviolet radiation and free radicals on the spore [20, $53,54]$. At the stage of germination, SPASs are used as a donor of amino acids [7, 54].

The effect of environmental factors on sporulation. Acting as a protective device for the survival of bacterial population, spores mediate the mechanisms providing their own extreme stability and maintaining the integrity of macromolecules (proteins, DNA) in the period of long quiescence. The structural endospore details (e.g. the arrangement of outer coatings) and their chemical composition may differ in various bacteria due to the diversity of the molecular mechanisms of their formation and the effect of the environmental factors on the effectiveness of sporulation $[48,50]$.

For instance, the effectivity of sporulation in the isolates of $B$. subtilis, $B$. anthracis, and $B$. cereus was maximal at optimal values of oxygen concentration, ionic medium composition, temperature, and $\mathrm{pH}$ while changes in these parameters resulted in the longer process of spore formation till its complete inhibition and to the reduction of their thermal resistance as well as the resistance to chemical and physical effects $[5,48,50$, 57]. Bressuire-Isoard et al. [57] showed that $B$. cereus spores formed at nonoptimal temperatures had a lower degree of dehydration and were less tolerant to wet heat. There are also other factors influencing the effectivity of sporulation. For example, Widderich et al. [31] found that high salinity (about $7 \%$ ) inhibits sporulation of $B$. subtilis at the early stage due to the impairment of coordination of $\sigma$-factor switching and blockage of signals of gene expression in the mother cell regulating the process of spore formation.

Molecular mechanisms regulating germination of bacterial spores. Of great scientific and practical interest is not only spore formation but the reverse process of spore germination which is also very sophisticated from the point of view of the molecular mechanisms regulating all successive stages. The process of germination is triggered in the external conditions favorable for a specific bacterial species. The most favorable medium for pathogenic microorganisms is an animal or human organism where they may develop, proliferate, and cause infectious diseases. $B$. anthracis endospores, in particular, transfer to the active form when they get into the lung tissue and cause a pulmonary form of anthrax [24, 58-60].

The mechanism of bacterial spore germination is initiated when nutrient substrates appear in the environment: carbohydrates, amino acids, purine bases, and when there is suitable humidity, aeration, and temperature. This process runs in several stages which are strictly regulated by the biochemical mechanisms [36, 42, 61]. Substances constituting the basis of bacterial nutrition irritate the receptor apparatus of the outer endospore membrane. The receptors, in their turn, activate the process of germination which becomes irreversible at a definite stage. The initial stage of germination is marked by the release of calcium dipicolinate, ions of $\mathrm{H}^{+}, \mathrm{Mn}^{2+}, \mathrm{Ca}^{2+}, \mathrm{Mg}^{2+}$. At this moment water is getting inside the cell, the $\mathrm{pH}$ value rises to 7.7, the glycopeptide complex is hydrolyzed [36, 60,61].

Concurrently with the changes in $\mathrm{pH}$, intracellular enzymes are activated, the metabolic processes and protein synthesizing mechanism are triggered. The cell is actively growing, swelling, increasing in volume $[5,42,57$, 62]. Once the intracellular pressure reaches the critical level, the endospore coating ruptures and a vegetative bacterial form emerges out of the spore coat [56].

These genetically determined molecular mechanisms of spore germination lie at the basis of the fractionated sterilization method (tyndallization): an object is exposed to steam at $100^{\circ} \mathrm{C}$ for half an hour. It is left then for a day at a temperature optimal for the growth and multiplication of microorganisms. Then the object is heated again with hot steam. This procedure is repeated several times. Bacteria managed to get out of the dormant state are destroyed affected by hyperthermia $[42,55]$.

In some bacteria, the process of germination has some supplementary specific features. It concerns the microorganisms capable of forming exosporium, the outermost spore coat, having specific morphofunctional characteristics.

\section{Morphofunctional characteristics of exosporium}

Spacial exosporium structure. As mentioned above, in the process of their sporulation some endospores of gram-positive bacteria form an additional outer protein layer, exosporium (exospore), which serves as a barrier between the exosporium and environment [21, 63, 64].

Neither Robert Koch who described first "a globular vitreous mass" (as cited in [21]) surrounding a spore, nor Karl Flügge who suggested the name "exosporium" (as cited in [14]) did not think that this "light narrow ring surrounding spores" (R. Koch) would appear to be such a complicated and interesting object with multi-vector functions when studied with the help of state-of-the-art methods of molecular biology.

In recent years, exosporium was investigated mainly on the isolates of three basic closely related species of spore-forming gram-positive bacteria (type Firmicutes) belonging to the group $B$. cereus sensu lato: $B$. anthracis, $B$. cereus, and $B$. thuringiensis (bacterial insecticide) $[3$, 64-67]. Besides some species of Clostridium spp. also form exospores [9, 32, 68-73].

The exospore architecture of bacteria of the mentioned groups does not significantly differ and has 
similar morphology [32, 69, 74]. Usually, it represents a flexible but tight coating, a thin continuous protein basal layer, which has external hairy and internal crystalline layers. Thin structures of the exosporium may change under various growth conditions and in different bacterial species [14, 66-68].

The application of the modern methods of molecular biology allowed scientists to expand the notion of the biochemical structure and spatial organization of exosporium. In bacteria of Bacillus spp. and Clostridium spp. family, exosporium has a thin and flexible coating structure whose volume is usually larger than that of the endospore being inside $[5,57,67]$.

As have been already indicated, the main structural element of exospores in various bacterial species is a thin crystalline basal protein layer [65, 70, 75-77]. The outer surface of the basal layer is coated by a hairy nap represented by collagen-like filaments, protein BclA, in the exosporium of bacteria of the $B$. cereus sensu lato group [32, 78-82]. This glycoprotein turned out to play a significant role in the protection of spores against phagocytosis [78, 83-85]. Besides, it has been proved to mediate the mechanism of immune inhibition which promotes the preservation of spores in the mouse lungs $[80,86,87]$.

In bacteria of $B$. cereus sensu lato group, the main elements of exosporium structure appeared to be similar $[78,81,84]$. As a rule, exospores have irregular balloonlike shape with multiple deformations, folds, and an endospore located inside.

The area between the basal layer of exosporium and the outer endospore coat is called an interspace [70, $80]$ and is equal to $500 \mathrm{~nm}$ in $B$. anthracis [77, 81]. In some places, the basal layer is located in the immediate proximity to the outer layer of the endospore coat. The basal layer of exosporium is about $12-16 \mathrm{~nm}$ thick (B. anthracis) and is likely to consist of two sublayers about $5 \mathrm{~nm}$ thick $[20,67,85]$.

Besides, the basal layer has a crystalline structural organization with a 6 -fold symmetry and a $7 \mathrm{~nm}$ periodic interval. The outer surface of this structure consists of a series of hexagonal concave cups arranged in a honeycomb pattern with open ends oriented outwards $[67,84,85]$. Semipermeable channels of $20-34 \mathrm{~nm}$ in diameter are located between the cups [20, 67] which is sufficient for penetration of low-molecular substances but too small for the diffusion of large molecular weight proteins. Such channel arrangement imparts the barrier properties to exosporium [20,67, 84].

The exospore nap filaments composed usually of BclA protein are $14-70 \mathrm{~nm}$ long and cover the entire surface of the outer coat of the basal layer [32, 84, 86-88]. The investigations [84, 88-91] showed that unlike other bacteria of $B$. cereus sensu lato group, the nap filaments in the exosporium of $B$. megaterium (strain QM B1551) were localized only on one pole and consisted of the $\mathrm{BclA}$ and $\mathrm{BclB}$ orthologous proteins and $B x p B(E x s F A)$ protein.
Synthesis of exosporium and its biochemical structure. The biochemical structure of exosporium differing substantially from that of endospores was the subject of numerous investigations [14, 24, 88, 92]. A general process of its biosynthesis has been illustrated on the conceptual "bottle cap" model and in respect to B. anthracis includes two stages [89-91]. Synthesis initiation occurs on the central pole of the spore. At first, a germ of the future exospore appears in the sporeforming mother cell as a small laminated structure. The exospore is assembled by the subsequent deposition of proteins: it begins with the synthesis of the "cap", the area located near the central pole of the mother cell including about $25 \%$ of the basal layer surface, and terminates by the formation of the remaining "bottle" part of the exosporium (about $75 \%$ ). Synthesis is completed on the opposite spore pole by attaching the exospore basal layer to the outer coat of the spore. The studies conducted in recent years on the strains $B$. anthracis and $B$. cereus have shown that a number of proteins are involved at different stages of separate part biosynthesis, which ultimately mediates its sophisticated biochemical structure [60, 75, 92-94].

Investigating the mutant isolates of $B$. anthracis, Boydston et al. [74] and Steichen et al. [16] were the first to find that the basal layer of the exosporium does not represent a biochemically uniform structure: its "cap" and "noncap" areas differ in the protein composition. Thus, CotY is the protein specific for the "cap" while proteins BclB, ExsY, BxpB (also known as ExsFA), ExsFB, and $B c l A$ are specific for the rest area of the exosporium [16, 74, 75, 92]. Of these proteins, CotY and ExsY participate in the biosynthesis of exosporium at the initial stages of forming the basal layer basis, whereas ExsFA and ExsFB at the final stages [74, 88]. ExsFA (exosporium protein with a mass of $17 \mathrm{kDa}$ ) is detected both in and beyond the "cap" area while its analog, $B x p B$, is mainly revealed in the "noncap" part of the exosporium [82, 90, 92]. Both these proteins (some authors put a sign of equality between them) are necessary at the stage of forming filaments of the nap layer [16, 67, 82, 90].

Among the proteins involved in the exosporium biosynthesis, a collagenic glycoprotein BclA deserves special attention. Experimental studies performed by Steichen et al. [16] and Brahmbhatt et al. [76] on the model of the recombinant glycated protein BclA of the $B$. anthracis isolate have found that this glycoprotein provides general hydrophobicity of exospores and also possesses immunodominant properties [16, 76, 77, 92]. This determines the potential capability of using BclA for the development of a vaccine against anthrax. In the experiments conducted, a specific antigen $\mathrm{rBclA}$ increased the defense of mice infected with $B$. anthracis spores and enhanced their phagocytosis decreasing concurrently the capacity of spore germination within macrophages which is known to be the key mechanism of anthrax pathogenesis [77, 78, 88, 92]. 
In the interface between the exo- and endospore, protein molecules CotY, ExsA, ExsB, ExsM, ExsY are detected which interact with the CotE endospore protein. These proteins ensure strong exospore anchoring [33, $57,66,74,88]$ and determine its chemical structure $[66$, 93-95].

During the exosporium coat synthesis, protein molecules are not involved in the process simultaneously. BclA and BxpB proteins are formed 4-5 $\mathrm{h}$ after the onset of spore formation. They are synthesized in the mother cell as a complicated high molecular weight structure. Then the proteins are divided into monomers and 60 min later the process of exosporium synthesis is triggered [89]. An interesting fact is that $\mathrm{Bcl} A$ and $\mathrm{BxpB}$ proteins are linked with each other due to the formation of the covalent bonds and thereafter the process of glycosylation is initiated [89, 90]. The bonds generated between these proteins are so strong that withstand boiling in the presence of $8 \mathrm{M}$ urea, $1 \%$ SDS, and reducing agents $[89,91]$.

Investigations carried out by Manetsberger et al. $[18,54]$ demonstrated that the cotW and $\cot X$ proteins encoded by the similarly-named genes are the main components of the basal layer of B.megaterium exospore just like the proteins CotY and ExsY in the structure of $B$. cereus and $B$. anthracis $[18,54,74,88$, 95]. In the spores of $B$. subtilis bacteria species, these protein molecules compose a tight outer coat which is likely to be an exospore rudiment $[62,96]$.

There are also works disclosing the most delicate molecular structure of exospores. Thompson et al. [90, 91] showed in their research the separation of the basal part of the coat into two (or possibly more) sublayers: an internal one with glycoproteins CotY and its paralog ExsY and an external sublayer including proteins BxpB and ExsFB.

The location of the definite protein molecules in different parts of the cell influences directly its properties [42]. For example, the BclA protein localized in the outermost structures protects the cell against phagocytes $[84,87]$ and immune agents [86, 97]. Exosporial enzymes inosine-hydrolase and alanine racemase [85, 88, 94] inhibit untimely spore germination $[98,99]$.

One of the candidates for a key protein component determining the structure and physiology of exosporium is ExsY. This is confirmed by the researches of Jiang et al. [26] and Terry et al. [63]. The investigators came to the conclusion that exosporium has hexagonal, honeycomb structure due to the ExsY protein. The authors believe that it becomes possible owing to the formation of the disulfide bonds between the cysteine of the protein chain and its subunits $[21,26,63]$. These bonds impart flexibility to the coat of Bacillus spp. and Clostridium spp. and at the same time high resistance to the external factors. Besides they make it possible to form the folds to provide a strong sticking to the surrounding objects $[74,88]$. The ability to adhere is known to be one of the key factors of virulence in this bacteria species $[8,9,20]$.
But it is not so unambiguous in relation to the bacteria of Clostridium genus. Interesting studies of the $C$. difficile exospore structure, the leading agent of nosocomial infection, were carried out by Calderón-Romero et al. [10]. They observed two morphotypes of exosporium differing in thickness in the endospores of these Clostridium genus representatives $[9,10,69,70,74]$. The external hairs were present in the strains of $C$. difficile in any case $[9,10,69]$. Analyzing the reasons of this phenomenon the authors suggested that the strains with different exospore thickness perform various functions during the development of the infection disease $[10,69,70]$.

The same researchers found 184 proteins in the exosporium layer using a gel-free approach for its analysis and combined methods of extraction [10, 70]. Some of the identified proteins turned out to be immunogenic (BclA, CdeC, CdeM, CotA, CotCB, CotE), they were defined as potential antigenic substances for vaccine creation $[65,70,99-101]$. In this group of proteins, special attention was paid to the collagen-like exosporium proteins BclA which form hairy filament structures [69, 70, 73]. C. difficile genomes encode three collagen-like BclA paralogs (BclA1, BclA2, BclA3) [65] which are localized only in the exosporium of the C. difficile spores [70, 73]. Taking into account that BclA2 and $\mathrm{BClA} 3$ are widely presented in the majority of the C. difficile strains, it may be supposed that vaccines on their basis will be able to provide immune defense against clinically significant isolates.

An important component of clostridium exosporium is $\mathrm{CdeC}$ and CdeM proteins rich in cysteine [10, 30, 64]. CdeM is encountered exclusively in $C$. difficile species [10] while $\mathrm{CdeC}$ was detected in other representatives of the Peptostreptococcaceae family [30]. When these proteins are not available, the bacterial pathogenicity is decreased [10].

The experiments have proved immunogenicity of the enumerated structural exosporium proteins $[30,64$, $102,103]$. The organism of mice which were injected with CdeM protein actively produced IgG-antibodies and developed immune response [103]. Post-vaccination defense after contamination with $C$. difficile reached $90 \%$. Hamsters were vaccinated with CdeM protein isolated from the recombinant strain $630 \mathrm{C}$. difficile. Its efficacy was $80 \%$ [102-104]. Investigations in this direction are being carried out taking into consideration the uniqueness of the CdeM protein for $C$. difficile. In particular, the efficacy of the constructed vaccine supplemented by adjuvants to accelerate and prolong its action is being studied [102, 105-109].

In addition to CdeM, another $C$. difficile protein, $\mathrm{CdeC}$, is also used for immunization of laboratory animals. Activation of humoral immunity with the production of $\operatorname{lgG}$ was achieved after 3-fold vaccination [103]. Consequently, this protein is also immunogenic $[3,64]$. Protection against $C$. difficile infection (strains 630, UK1) after vaccination and the survival of the immunized animals reached $100 \%[9,69]$. 
The role of exosporium in the pathologic process. The main object in the investigation of the role of exosporium in the infectious process is antropozoonotic agent of anthrax, $B$. anthracis, capable of forming spores under aerobic conditions [14, 84, 89-94].

The initial stage of organism contamination occurs, to the large extent, with an active participation of exosporium, i.e. during the interaction of its superficial collagen BclA glycoprotein with the integrin Mac-1 (CR3) $[26,60,110]$. When the agent spores enter the host organism, they are absorbed by macrophages and dendrite cells which initiate clinical manifestations and the form of the disease (pulmonary, cutaneous, or gastrointestinal) $[89,90,100,111,112]$. In any disease form, phagocytes migrate with the lymph flow generating the process. Spores germinate inside the phagocytes and dendrite cells, multiply, and produce toxins. In the lymphatic nodes cell lysis and release of the vegetative bacterial forms take place with subsequent invasion to the blood flow, active proliferation, and toxin production mediating clinical manifestations of the infection and resulting in lethal outcome. The next stage of spore formation goes on in soil only, where there is enough oxygen which is the inductor of sporulation $[78,79,110]$.

Thus, a key link in the infectious process is binding of the causative agent spore to integrin and their phagocytosis. Oliva et al. [110] and Bozue et al. [78] have demonstrated that $B$. anthracis spores deprived of the $B c / A$ protein do not bind to the integrin. Rhamnose contained in the BclA was shown to bind to CD14 and to act as a coreceptor during Mac-1 integrin interaction promoting phagocytosis. The data presented indicate to the leading role of the exosporium BclA glycoprotein in the pathogenesis of anthrax.

Despite a significant progress in the understanding of the structure and functions of exospores achieved in recent years, our notion of the composition, mechanisms of their generation and the role of this outer structure of bacterial spores remains insufficient [10, 14, 33, 113]. Obviously, investigations began in the XIX century by $R$. Koch should be continued and much is to be discovered in relation to the biology of exospores.

Application of the state-of-the-art analytical tools used for studying the microbiology of single cells for the exploration of these structures (atomic-force microscopy, Raman spectroscopy, genetics) may become a key to a more comprehensive understanding of the morphological, nanomechanical, and biochemical characteristic of exosporium [12, 113, 114].

\section{Modern technologies for identification and investigations of spores}

Atomic-force microscopy: from visualization to atomic manipulation. Scanning probe microscopy is one of the most dynamically developing analytical technologies actively used in current scientific research. One of the most known instruments is an atomic-force microscope invented in 1986 as a scanning tunneling profilometer [28]. Since the 90s of the last century, the atomic-force microscopy (AFM) has been used most actively in biomedical investigations owing to a simple procedure of sample preparation and the capability of submicron visualization of the objects [28, 115-118]. Within a short period of time, AFM as a method of 3D imaging and examining local micromechanical properties has won the leading positions in various fields of science including microbiological investigations [28, 116, 119]. This analytical instrument has supplemented and broadened the potential of the visualization method which is basic for microbiologists, i.e. light microscopy, going beyond its technical resolution, and electron microscopy with its main drawback consisting in the complexity of sample preparation and the necessity to investigate under conditions of a high vacuum [116, 120,121].

Atomic-force microscopy is attractive for microbiology due to some specific technical features of this diagnostic method based not on the lens properties but rather on the application of a special probe (sensor) and flexible resilient cantilever mounted in the holder.

This imaging instrument combines microscopy in its usual form with nanomolecular detection of mechanical, immunochemical, adhesive, and electrostatic properties of the object (bacteria). These capabilities made AFM an extremely useful and indispensable tool in molecular microbiology, and the prokaryote cells owing to their size and properties became an advantageous object for the study $[116,122,123]$. As a result of scanning, AFM provides a digital three-dimensional topographic image of the microorganism surface in the nanometer lateral and special resolution in any medium and at different temperatures [121, 123].

During a short period of time, AFM turned from the method of topographic imaging into the instrument of separate atom manipulation and investigation of molecular interaction. The capabilities of AFM in the study of bacterial spores will be considered below.

Periodic atomic-force observations of bacterial endospores allow tracking the dynamic processes connected with sporulation or germination into the vegetative cells. It is essential for the microbiologic investigations that AFM can be performed in several modes. In the topographic mode ("constant force") the displacement of the cantilever is maintained constant using a feedback loop. The force of stylus interaction with the sample surface depends considerably on the distance between them and is determined by adhesion and also by the Van der Waals and capillary interactions. Z-position of the cantilever reflects the sample topography (the height) like a geographic map where the color of the image corresponds to the relief height [116, 118, 123].

Being the method of the force probing, AFM allows one not only to obtain the image of the surface topography and multilayer spore architecture but to determine their nanomechanical characteristics such as 
resilience, viscosity, and adhesion [12, 121-123]. It is possible to acquire information on the sample surface topography using Young modulus (modulus of elasticity) and adhesion as a high-resolution image $[115,118,124]$. For example, in the studies performed by Giorno et al. $[24,60]$ and Brunsing et al. [27] with the help of AFM in the aqueous solutions, it has been found that the surface of the Bacillus spp. spores has a number of round ribbed nanometer projections on the outer coat oriented along the longitudinal axis, while Zolock et al. [125] showed that based on these morphological features four closely related species of Bacillus spores can be differentiated.

Visualization of the spores in a liquid opens wide perspectives for the monitoring of dynamic processes such as sporulation and germination of the dormant cellular forms. Recent interesting examples are the studies of the germination dynamics of Bacillus spp. spores into the vegetative cells. After 30 min incubation at room temperature, the spore size increase (swelling) was observed and 5-6 $\mathrm{h}$ later the spore outgrew into the vegetative cells which immediately formed a biofilm $[121,123]$.

Modern capabilities of using AFM for studying the nanomechanical properties of the $B$. anthracis spore inner structures have been demonstrated by $\mathrm{Li}$ et al. [12] and Morisaku et al. [123]. On the basis of the thermoprobe AFM (scanning thermal microscopy, SThM) they developed a technique of nanosurgical cutting of the spore using a hard diamond tip while a soft probe was applied for visualization and characteristic of its inner structure in the nanometer scale. It has been found that values of elasticity and adhesion at high temperatures vary in different regions of the spore section [123], there also was detected a previously unknown peptidoglycan ultrastructure of the $B$. anthracis spore cortex consisting of the rod-shaped nanometer structures oriented in the transverse direction relative to the longitudinal spore axis $[12,123]$.

For almost a 30-year history of employment in the molecular microbiology, force microscopy became a powerful research tool in the exploration of spores effectively supplementing light microscopy, genetics, and biochemical methods traditionally used to analyze the cellular wall structure of dormant bacterial forms. However, the potential application of this technique in the study of dormant bacterial cellular forms is still underestimated and is limited only by some of its functional capabilities [114, 126]. Further application of AFM is connected with the employment of dynamic (multifrequency, multiharmonic, bimodal) techniques which allow one to obtain faster quantitative nanomechanical characteristics of the complex multilayer spore structures with a higher resolution [123, 127].

Interesting and promising is the development and application of AFM biosensors for the quantitative visualization of separate molecules of endospores and exosporium structural proteins using G-quadruplex DNA technologies or functionalized probes with immobilized chemical groups of single molecules especially in combination with other analytical tools such as Raman scattering spectroscopy [126-128].

Raman spectroscopy: new capabilities of the old technique. The development of highly sensitive and fast methods of detecting bacterial spores is a challenging task for medical diagnosis, epidemiology, and for solving the tasks of biosafety.

A public outcry caused by the bioterrorist attack in 2001 in which the spores of $B$. anthracis were used has sharpened the problem of their long detection and identification. It was necessary to grow the material in the nutrient media till the vegetative cellular forms and biomass accumulation, and finally to conduct molecular genetic investigations in order to reveal 16S pRNA gene specific for this type of pathogen. Besides, similar investigations lasting several hours have to be conducted with other suspicious powders to evaluate the scale of the assault $[79,129,130]$. As a result, it was recognized that new informative and more rapid detection methods are required. Early information on pathogen identification would have accelerated the beginning of specific preventive measures, etiopathogenetic treatment, and would have minimized tragic consequences of the terrorist attack caused by the number of infected and died people [27, 131, 132].

The problem of rapid identification is complicated by some aspects connected with the minimal amount of the examined material (inhaling only $10^{4}$ of $B$. anthracis endospores (100 ng of powder) is a fatal dose for $50 \%$ of the infected people) and with the necessity to differentiate the pathogenic biosubstrate from the similar but harmless substance to eliminate the panic fear accompanying the epidemic outbreaks of dangerous infections [99, 129, 133]. Therefore, a new indication method must be not only fast but highly specific, reliably differentiating dangerous bacterial endospores from other biological objects anywhere in the environment.

Raman scattering spectroscopy (RS) meets these criteria being known over 80 years and widely used for a long time as an analytical and applied tool in chemical and technical branches [52, 86, 117]. Low intensity of the signal obtained from the live object has long been an obstacle for the application of RS in biomedical investigations. However, after the improvement of this technology in the last 10-20 years (primarily the integration of RS with confocal microscope and various means of the scattering signal amplification) it is widely used for biomedical investigations requiring no time for sample preparation, special marking, or staining [117]. This powerful analytical tool has been actively employed in recent years for fast, inexpensive, and effective solution of the tasks in molecular microbiology [52].

Raman spectroscopy is attractive owing to its noninvasiveness (the capacity to examine bacteria not destroying them), minimal sample preparation, absence of marks and probes, and the rate of obtaining the result. 
The examined sample is placed in focus of the excitation laser and measured. Molecular information acquired by RS makes it possible to identify unambiguously the microorganism according to the specific spectrum of the chemical and biochemical substances which it is composed of $[129,131,132]$. Besides, the possibility to obtain data on the molecular structure of the bacterial cells which are at different stages of their life cycle as well as to study the dynamics of some cellular processes made this technique a powerful analytical tool for spore exploration (Figure 3 ).

Significant differences in the spectra of the Raman scattering for the vegetative and spore cellular forms of bacteria were detected relatively long ago investigating Bacillus spp. These differences are related to the predominance of calcium dipicolinate in the resonance spectrum of the bacterial endospores whose major peaks were found at the oscillation frequencies of 1015$1017 \mathrm{~cm}^{-1}$ and $244 \mathrm{~nm}$ excitation wavelength [22, 43, 44, $47,133]$. As pointed above, the content of this marker amounted on average to $10 \%$ of a dry spore mass and vary dependent on the species, spore-forming bacterial strain, and sporulation conditions [37, 40, 43, 47]. The obtained Raman spectra of $B$. cereus, B. anthracis, and $B$. subtilis spores appeared to be very similar and calcium dipicolinate was proposed as a sensitive biomarker for a rapid detection of Bacillus spp. spores [134-136].

In recent years, investigations of bacterial spores are carried out using improved RS modifications amplifying the signal (employment of the resonance excitation frequency, laser optic forceps, silver and gold nanoparticles, or coherent anti-Stokes Raman scattering) [135]. Thus, Wang et al. [1, 137] studied the kinetics and levels of accumulation of berberine alkaloid in the Bacillus spp. and Clostridium spp. spores and its effect on their germination. The aim of the study was to find the means of minimizing potential danger of the germinated spores and the methods of their elimination after or during their germination. In this work, RS laser forceps in combination with fluorescence and differential interference microscopy were utilized to analyze localization, level, and kinetics of berberine absorption in a separate dormant and germinating spore.

The combination of AFM and RS techniques is thought to be very perspective for the investigations of bacterial spores. These integrated analytical systems have been used in molecular microbiology in recent years [48, 117]. Information about the structural topography and nanomechanical properties is supplemented with the data about a submicron molecular profile which gives a fairly complete picture and better understanding of the dormant systems [117]. For example, Boitor et al. [138] have evaluated quantitatively RNA, DNA, and proteins of the bacterial cellular forms by recording the Raman spectra and calibrating models for each structural component and correction of focus effects using AFM topographic images.

One of the latest modifications of this method, the combination of RS with confocal microscopy, contributed to the appearance of a powerful instrument for the study of bacterial spores, micro Raman spectroscopy (microRS). This perspective technique renders a unique possibility for the investigation of separate cells

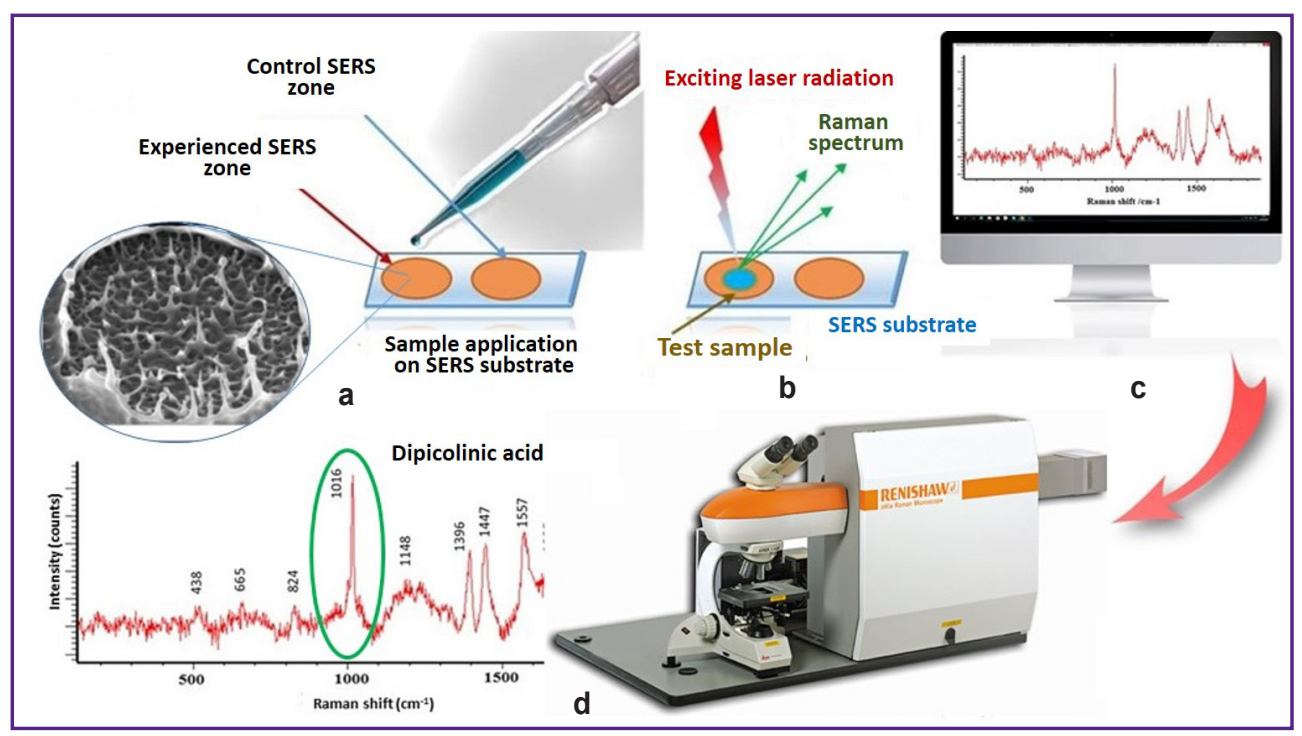

Figure 3. Surface-enhanced Raman spectroscopy (SERS) is the most promising analytical tool for spore indication:

(a) application of the sample on the silver or golden SERS-active substrate treated by laser;

(b) treatment of the sample by excitation laser beam of a definite wavelength; (c) scattering of Raman rays; (d) recording of Raman spectrum using Raman confocal microscope (photo and drawing courtesy of the authors) 
and cellular elements. Recent investigations of the bacterial spores of the species of Bacillus genus using microRS [137-139] made it possible to obtain interesting findings on their phenotypic heterogeneity related to the environmental parameters and also to test individually methods of inactivation of these cellular forms. Sporicidal capability of some physical and chemical methods was evaluated at the level of separate spores and, ultimately, treatment with $20 \%$ formaldehyde appeared to be most effective [138]. Besides, the cold atmospheric plasma has been shown to inactivate the spores highly effectively and prospectively in the medical and food industries [137, 139].

In recent years, spectroscopic methods for the bacterial spore investigations attracted attention as the main element for the combination with other analytical instruments $[52,117,139]$. This interdisciplinary approach reflects a new trend and is an indispensable research technology of multiparametric exploration of heterogeneity of single cells in microbiology (a paradigm of unicellular microbiology) including bacterial spores. And in this regard, AFM and RS serve as examples of novel analytical tools and techniques which render a unique possibility to observe discrete microbiological phenomena unavailable which traditional approaches are not able to realize.

\section{Plasmochemical technologies and bacterial spores}

Bacterial spores have been known since the emergence of microbiology as a science. For a long time, they have been considered from the point of view of their epidemiologic and pathogenetic importance for the occurrence of infections. As mentioned above, extreme stability in the environment made bacterial spores a serious problem of public health. The existing sterilization methods (dry and wet steam, chloridecontaining substances, $\gamma$-irradiation, and others) are not sufficiently effective especially during decontamination of surgical instruments, medical equipment, or pharmaceuticals. Therefore, the search for the means and methods of bacterial spore elimination was and remains a challenging scientific task which is being solved by involving numerous interdisciplinary investigations.

To realize this goal, the possibility of using nonthermal ambient-temperature (cold) plasma is actively studied since it may be employed for the treatment of thermosensitive objects and is considered as a potential alternative to the traditional sterilization methods [137, 139, 140]. Such plasma is generated by the exposure of gas (some inert gas, for example) to electric or electromagnetic fields. The field energy causes acceleration of free electrons and ionizes the gas atoms and molecules. Excited atoms and molecules returning to the more stable state release excess energy in the form of electromagnetic or ultraviolet radiation and as active forms of oxygen and nitrogen with a wide and powerful antimicrobial spectrum of action [141-143]. The most studied applications of this technology in biology and medicine are food sterilization, decontamination of medical equipment, surgical implants, and treatment of wound surfaces [142, 144-146].

Rapid (seconds/minutes) and effective effect of the cold plasma on dormant and vegetative cellular forms of pathogenic gram-negative and gram-positive bacteria including Bacillus spp. and Clostridium spp. spores attracted great interest of microbiologists [145, 147, 148]. It was focused primarily on the study and characteristic of plasma antimicrobial effectivity and mechanisms of microbial inactivation and sporicidal action which are presently being actively studied [141, 149, 150].

\section{Conclusion}

Bacterial spores are a unique and highly inert biological system with mechanisms of resistance to the extreme conditions which are not completely studied. Understanding the mechanisms of stability of these dormant forms is of great biomedical importance and can potentially lead to the development of novel methods of prophylaxis and sterilization which will be directed to the vulnerable structures of endo- and exospores.

A long-term history of studying endospores allowed microbiologists to analyze in detail and describe the process of sporulation and germination in separate model organisms, to create a firm basis for understanding the cellular processes leading to the generation of these dormant forms, to become partially aware of the diverse mechanisms of their tolerance. The result of the investigations became a conceptual persuasion that high stability of the bacterial spores may be important and find application in various fields of biotechnology.

Presently, the exploration of the spores goes on at a new nanostructural level. For instance, spores are of scientific interest as a biological model for studying the mechanisms of generating complicated supramolecular structures and become a target for modern biotechnologies following the principle "to learn from nature" [150-152]. Very perspective are the developments of the models of endospore natural architectonics for creation of self-organizing supramolecular structures used as nanodimensional substrates for packing and target delivery of enzymes, nucleic acids, antigens, and drugs to the definite tissues, cells and even intracellular organelles [153-155]. These surfaces may be used as biocoatings or molecular switchers activated by chemical substances, electrons, or light [156, 157].

A direct utilization of endospore is also considered though there is a significant risk of germination and vegetative growth of bacteria before they reach the target tissue. Nevertheless, Roberts et al. [154] used endospores of $C$. histolyticum and $C$. novyi in the 
experiment and found that these species caused lysis of the tumor cells or tumor regression during germination and vegetative growth.

Another direction connected with the application of spores in the treatment of malignant tumors is a selective expression of specific enzymes in the predominant germination of dormant in hypoxic tumors [155].

From the beginning of the XXI century, researches have been carried out on the usage of recombinant bacterial spores for creation of thermostable vaccines [149, 151, 158-160]. In 2007, Uyen et al. [153] conducted a successful experiment on protection of mice against tetanus by oral and nasal introduction of the vaccines constructed on the bases of antigen $C$. tetani TTFC on the surface of $B$. subtilis spores. The conducted pilot studies proved the prospectivity of these biotechnologies [156, 157, 161].

It has been supposed in recent publications [10, 36, $152,162]$ that spores and spore-forming bacteria may play an important role in the development and spread of resistance to antibiotics due to their biological properties, ability to dissemination and thereby to the propagation of resistance genes to antimicrobial substances in the state of metabolic rest $[10,36,152]$.

In the nearest future, the unique properties of bacterial spores are believed to find their application in other ecosystemic technologies, for example, in paleoecologic probing, as biofungicides and bioinseticides in agriculture, as well as during bioremediation and biomineralization (biologically induced and controlled processes of mineralization that go on in nature).

Authors' contributions. Each of the authors contributed equally to the manuscript writing.

Research funding. The work was not supported by any financial sources.

Conflicts of interest. The authors have no conflicts of interest to declare.

\section{References}

1. Wang S., Shen A., Setlow P., Li Y.Q. Characterization of the dynamic germination of individual Clostridium difficile spores using Raman spectroscopy and differential interference contrast microscopy. J Bacteriol 2015; 197(14): 2361-2373, https://doi.org/10.1128/JB.00200-15.

2. Rosales-Mendoza S., Angulo C., Meza B. Foodgrade organisms as vaccine biofactories and oral delivery vehicles. Trends Biotechnol 2016; 34(2): 124-136, https://doi. org/10.1016/j.tibtech.2015.11.007.

3. Barra-Carrasco J., Paredes-Sabja D. Clostridium difficile spores: a major threat to the hospital environment. Future Microbiol 2014; 9(4): 475-486, https://doi.org/10.2217/fmb.14.2.

4. Abhyankar W., Pandey R., Ter Beek A., Brul S., De Koning L.J., De Koster C.G. Reinforcement of Bacillus subtilis spores by cross-linking of outer coat proteins during maturation. Food Microbiol 2015; 45 (Pt A): 54-62, https://doi. org/10.1016/j.fm.2014.03.007.

5. Bressuire-Isoard C., Broussolle V., Carlin F. Sporulation environment influences spore properties in Bacillus: evidence and insights on underlying molecular and physiological mechanisms. FEMS Microbiol Rev 2018; 42(5): 614-626, https://doi.org/10.1093/femsre/fuy021.

6. Nicholson W.L. Roles of Bacillus endospores in the environment. Cell Mol Life Sci 2002; 59(3): 410-416, https:// doi.org/10.1007/s00018-002-8433-7.

7. Paredes-Sabja D., Shen A., Sorg J.A. Clostridium difficile spore biology: sporulation, germination, and spore structural proteins. Trends Microbiol 2014; 22(7): 406-416, https://doi.org/10.1016/j.tim.2014.04.003.

8. Rupnik M., Wilcox M.H., Gerding D.N. Clostridium difficile infection: new developments in epidemiology and pathogenesis. Nat Rev Microbiol 2009; 7(7): 526-536, https:// doi.org/10.1038/nrmicro2164.

9. Pizarro-Guajardo M., Chamorro-Veloso N., Vidal R.M., Paredes-Sabja D. New insights for vaccine development against Clostridium difficile infections. Anaerobe 2019; 58: 73 79, https://doi.org/10.1016/j.anaerobe.2019.04.009.

10. Calderón-Romero P., Castro-Córdova P., ReyesRamírez R., Milano-Céspedes M., Guerrero-Araya E., PizarroGuajardo M., Olguín-Araneda V., Gil F., Paredes-Sabja D. Clostridium difficile exosporium cysteine-rich proteins are essential for the morphogenesis of the exosporium layer, spore resistance, and affect C. difficile pathogenesis. PLoS Pathog 2018; 14(8): e1007199, https://doi.org/10.1371/journal. ppat.1007199.

11. McDonald L.C., Gerding D.N., Johnson S., Bakken J.S., Carroll K.C., Coffin S.E., Dubberke E.R., Garey K.W., Gould C.V., Kelly C., Loo V., Shaklee S.J., Sandora T.J., Wilcox M.H. Clinical practice guidelines for Clostridium difficile infection in adults and children: 2017 update by the Infectious Diseases Society of America (IDSA) and Society for Healthcare Epidemiology of America (SHEA). Clin Infect Dis 2018; 66(7): 987-994, https://doi.org/10.1093/cid/ciy149.

12. Li A.G., Burggraf L.W., Xing Y. Nanomechanical characterization of Bacillus anthracis spores by atomic force microscopy. Appl Environ Microbiol 2016; 82(10): 2988-2999, https://doi.org/10.1128/AEM.00431-16.

13. Fritze D. Taxonomy of the genus Bacillus and related genera: the aerobic endospore-forming bacteria. Phytopathology 2004; 94(11): 1245-1248, https://doi. org/10.1094/phyto.2004.94.11.1245.

14. Stewart G.C. The exosporium layer of bacterial spores: a connection to the environment and the infected host. Microbiol Mol Biol Rev 2015; 79(4): 437-457, https://doi. org/10.1128/MMBR.00050-15.

15. Tan I.S., Ramamurthi K.S. Spore formation in Bacillus subtilis. Environ Microbiol Rep 2014; 6(3): 212-225, https://doi. org/10.1111/1758-2229.12130.

16. Steichen C., Kearney J.F., Turnbough C.L. Jr. Nonuniform assembly of the Bacillus anthracis exosporium and a bottle cap model for spore germination and outgrowth. Mol Microbiol 2007; 64(2): 359-367, https://doi.org/10.1111/j.13652958.2007.05658.x.

17. Thompson B.M., Waller L.N., Fox K.F., Fox A., Stewart G.C. The BclB glycoprotein of Bacillus anthracis is involved in exosporium integrity. J Bacteriol 2007; 189(18): 6704-6713, https://doi.org/10.1128/jb.00762-07.

18. Manetsberger J., Ghosh A., Hall E.A.H., Christie G. Orthologues of Bacillus subtilis spore crust proteins have a structural role in the Bacillus megaterium QM B1551 spore exosporium. Appl Environ Microbiol 2018; 84(20): e01734-18, https://doi.org/10.1128/aem.01734-18. 
19. Russell J.R., Cabeen M.T., Wiggins P.A., Paulsson J., Losick R. Noise in a phosphorelay drives stochastic entry into sporulation in Bacillus subtilis. EMBO J 2017; 36(19): 28562869, https://doi.org/10.15252/embj.201796988.

20. Kailas L., Terry C., Abbott N., Taylor R., Mullin N., Tzokov S.B., Todd S.J., Wallace B.A., Hobbs J.K., Moir A., Bullough P.A. Surface architecture of endospores of the Bacillus cereus/anthracis/thuringiensis family at the subnanometer scale. Proc Natl Acad Sci U S A 2011; 108(38): 16014-16019, https://doi.org/10.1073/pnas.1109419108.

21. Terry C., Shepherd A., Radford D.S., Moir A., Bullough P.A. YwdL in Bacillus cereus: its role in germination and exosporium structure. PLoS One 2011; 6: e23801, https:// doi.org/10.1371/journal.pone.0023801.

22. Cetinkaya Y., Yurt M.N.Z., Avni Oktem H., Yilmaz M.D. A monostyryl boradiazaindacene (BODIPY)-based lanthanidefree colorimetric and fluorogenic probe for sequential sensing of copper (II) ions and dipicolinic acid as a biomarker of bacterial endospores. J Hazard Mater 2019; 377: 299-304, https://doi.org/10.1016/j.jhazmat.2019.05.108.

23. Errington J. Regulation of endospore formation in Bacillus subtilis. Nat Rev Microbio/ 2003; 1(2): 117-126, https:// doi.org/10.1038/nrmicro750.

24. Giorno R., Bozue J., Cote C., Wenzel T., Moody K.S., Mallozzi M., Ryan M., Wang R., Zielke R., Maddock J.R., Friedlander A., Welkos S., Driks A. Morphogenesis of the Bacillus anthracis spore. J Bacteriol 2007; 189(3): 691-705, https://doi.org/10.1128/JB.00921-06.

25. McKenney P.T., Driks A., Eichenberger P. The Bacillus subtilis endospore: assembly and functions of the multilayered coat. Nat Rev Micro 2013; 11(1): 33-44, https:// doi.org/10.1038/nrmicro2921.

26. Jiang S., Wan Q., Krajcikova D., Tang J., Tzokov S.B., Barak I., Bullough P.A. Diverse supramolecular structures formed by self-assembling proteins of the Bacillus subtilis spore coat. Mol Microbiol 2015; 97(2): 347-359, https://doi. org/10.1111/mmi.13030.

27. Brunsing R.L., La Clair C., Tang S., Chiang C., Hancock L.E., Perego M., Hoch J.A. Characterization of sporulation histidine kinases of Bacillus anthracis. J Bacteriol 2005; 187(20): 6972-6981, https://doi.org/10.1128/jb.187.20. 6972-6981.2005.

28. Pratda V.G., Sanstad E.A., Wang R., Driks A. Morphogenesis of Bacillus spore surfaces. J Bacteriol 2003; 185(21): 6255-6261, https://doi.org/10.1128/jb.185.21.62556261.2003.

29. Setlow P. Spores of Bacillus subtilis: their resistance to and killing by radiation, heat and chemicals. J Appl Microbiol 2006; 101(3): 514-525, https://doi.org/10.1111/j.1365-2672.2005. 02736.x.

30. Hong H.A., Hitri K., Hosseini S., Kotowicz N., Bryan D., Mawas F., Wilkinson A.J., van Broekhoven A., Kearsey J., Cutting S.M. Mucosal antibodies to the $C$ terminus of toxin A prevent colonization of Clostridium difficile. Infect Immun 2017; 85(4): e01060-16, https://doi.org/10.1128/iai.01060-16.

31. Widderich N., Rodrigues C.D.A., Commichau F.M., Fischer K.E., Ramirez-Guadiana F.H., Rudner D.Z., Bremer E. Salt-sensitivity of $\sigma \mathrm{H}$ and SpoOA prevents sporulation of Bacillus subtilis at high osmolarity avoiding death during cellular differentiation. Mol Microbiol 2016; 100(1): 108-124, https://doi.org/10.1111/mmi.13304.

32. Janganan T.K., Mullin N., Tzokov S.B., Stringer S., Fagan R.P., Hobbs J.K., Moir A., Bullough P.A. Characterization of the spore surface and exosporium proteins of Clostridium sporogenes; implications for Clostridium botulinum group I strains. Food Microbiol 2016; 59: 205-212, https://doi. org/10.1016/j.fm.2016.06.003.

33. Bailey-Smith K., Todd S.J., Southworth T.W., Proctor J., Moir A. The ExsA protein of Bacillus cereus is required for assembly of coat and exosporium onto the spore surface. J Bacteriol 2005; 187(11): 3800-3806, https://doi.org/10.1128/ jb.187.11.3800-3806.2005.

34. Logan N.A. Bacillus and relatives in foodborne illness. J Appl Microbiol 2012; 112(3): 417-429, https://doi.org/10.1111/ j.1365-2672.2011.05204.x.

35. Hosoya S., Lu Z., Ozaki Y., Takeuchi M., Sato T. Cytological analysis of the mother cell death process during sporulation in Bacillus subtilis. J Bacteriol 2007; 189(6): 25612565, https://doi.org/10.1128/jb.01738-06.

36. Setlow P. Spore resistance properties. Microbiol Spectr 2014; 2(5), https://doi.org/10.1128/microbiolspec.TBS-0003-2012.

37. Batalha I.L., Ke P., Tejeda-Montes E., Uddin S., van der Walle C.F., Christie G. Dipicolinic acid as a novel spore-inspired excipient for antibody formulation. Int J Pharm 2017; 526(1-2): 332-338, https://doi.org/10.1016/j.ijpharm.2017.05.012.

38. Scheldeman P., Herman L., Foster S., Heyndrickx M. Bacillus sporothermodurans and other highly heatresistant spore formers in milk. J Appl Microbiol 2006; 101(3): 542-555, https://doi.org/10.1111/j.1365-2672.2006.02964.x.

39. Schubert W.W., Beaudet R.A. Determination of lethality rate constants and D-values for heat-resistant Bacillus spores ATCC 29669 exposed to dry heat from $125^{\circ} \mathrm{C}$ to $200^{\circ} \mathrm{C}$. Astrobiology 2011; 11(3): 213-223, https://doi.org/10.1089/ ast.2010.0502.

40. Cheung M., Lee W.W., Cowcher D.P., Goodacre R., Bell S.E. SERS of meso-droplets supported on superhydrophobic wires allows exquisitely sensitive detection of dipicolinic acid, an anthrax biomarker, considerably below the infective dose. Chem Commun (Camb) 2016; 52(64): 9925-9928, https://doi.org/10.1039/c6cc03521c.

41. Di Filippo P., Pomata D., Riccardi C., Buiarelli F., Uccelletti D., Zanni E. Muramic and dipicolinic acids in atmospheric particulate matter as biomarkers of bacteria and bacterial spores. Anal Bioanal Chem 2017; 409(6): 1657-1666, https://doi.org/10.1007/s00216-016-0111-y.

42. Setlow P. I will survive: DNA protection in bacterial spores. Trends Microbiol 2007; 15(4): 172-180, https://doi. org/10.1016/j.tim.2007.02.004.

43. Pestov D., Zhi M., Sariyanni Z.E., Kalugin N.G., Kolomenskii A.A., Murawski R., Paulus G.G., Sautenkov V.A., Schuessler H., Sokolov A.V., Welch G.R., Rostovtsev Y.V., Siebert T., Akimov D.A., Graefe S., Kiefer W., Scully M.O. Visible and UV coherent Raman spectroscopy of dipicolinic acid. Proc Natl Acad Sci U S A 2005; 102(42): 14976-14981, https://doi.org/10.1073/pnas.0506529102.

44. Slieman T.A., Nicholson W.L. Role of dipicolinic acid in survival of Bacillus subtilis spores exposed to artificial and solar UV radiation. Appl Environ Microbiol 2001; 67(3): 12741279, https://doi.org/10.1128/aem.67.3.1274-1279.2001.

45. Driks A. The dynamic spore. Proc Natl Acad Sci U S A 2003; 100(6): 3007-3009, https://doi.org/10.1073/ pnas. 0730807100 .

46. Wang C., Ehrhardt C.J., Yadavalli V.K. Single cell profiling of surface carbohydrates on Bacillus cereus. J R Soc Interface 2015; 12(103): 20141109, https://doi.org/10.1098/ rsif.2014.1109. 
47. Bai X.R., Zeng Y., Zhou X.D., Wang X.H., Shen A.G., $\mathrm{Hu}$ J.M. Environmentally safe mercury(II) ions aided zerobackground and ultrasensitive SERS detection of dipicolinic acid. Anal Chem 2017; 89(19): 10335-10342, https://doi. org/10.1021/acs.analchem.7b02172.

48. Gao L., Zhao H., Li T., Huo P., Chen D., Liu B. Atomic force microscopy based tip-enhanced Raman spectroscopy in biology. Int J Mol Sci 2018; 19(4): E1193, https://doi. org/10.3390/ijms19041193.

49. Wrobel T.P., Bhargava R. Infrared spectroscopic imaging advances as an analytical technology for biomedical sciences. Anal Chem 2018; 90(3): 1444-1463, https://doi. org/10.1021/acs.analchem.7b05330.

50. Westphal A.J., Price P.B., Leighton T.J., Wheeler K.E. Kinetics of size changes of individual Bacillus thuringiensis spores in response to changes in relative humidity. Proc Natl Acad Sci U S A 2003; 100(6): 3461-3466, https://doi. org/10.1073/pnas.232710999.

51. Higgins D., Dworkin J. Recent progress in Bacillus subtilis sporulation. FEMS Microbiol Rev 2012; 36(1): 131148, https://doi.org/10.1111/j.1574-6976.2011.00310.x.

52. Kong M., Na H., Ha N.C., Ryu S. LysPBC2, a novel endolysin harboring a Bacillus cereus spore binding domain. Appl Environ Microbiol 2019; 85(5): e02462-18, https://doi. org/10.1128/aem.02462-18.

53. Lequette Y., Garénaux E., Combrouse T., Del Lima Dias T., Ronse A., Slomianny C., Trivelli X., Guerardel Y., Faille $C$. Domains of BclA, the major surface glycoprotein of the $\mathrm{B}$. cereus exosporium: glycosylation patterns and role in spore surface properties. Biofouling 2011; 27(7): 751-761, https://doi.org/10.1080/08927014.2011.599842.

54. Manetsberger J., Hall E.A.H., Christie G. Plasmidencoded genes influence exosporium assembly and morphology in Bacillus megaterium QM B1551 spores. FEMS Microbiol Lett 2015; 362(18): fnv147, https://doi.org/10.1093/femsle/fnv147.

55. Abhyankar W.R., Kamphorst K., Swarge B.N., van Veen H., van der Wel N.N., Brul S., de Koster C.G., de Koning L.J. The influence of sporulation conditions on the spore coat protein composition of Bacillus subtilis spores. Front Microbiol 2016; 7: 1636, https://doi.org/10.3389/ fmicb.2016.01636.

56. Checinska A., Paszczynski A., Burbank M. Bacillus and other spore-forming genera: variations in responses and mechanisms for survival. Annu Rev Food Sci Technol 2015; 6: 351-369, https://doi.org/10.1146/annurev-food$030713-092332$.

57. Bressuire-Isoard C., Bornard I., Henriques A.O., Carlin F., Broussolle V. Sporulation temperature reveals a requirement for CotE in the assembly of both the coat and exosporium layers of Bacillus cereus spores. Appl Environ Microbiol 2016; 82(1): 232-243, https://doi.org/10.1128/ AEM.02626-15.

58. Ireland J.A., Hanna P.C. Amino acid- and purine ribonucleoside-induced germination of Bacillus anthracis DeltaSterne endospores: gerS mediates responses to aromatic ring structures. J Bacteriol 2002; 184(5): 1296-1303, https:// doi.org/10.1128/jb.184.5.1296-1303.2002.

59. Cybulski R.J. Jr., Sanz P., McDaniel D., Darnell S., Bull R.L., O'Brien A.D. Recombinant Bacillus anthracis spore proteins enhance protection of mice primed with suboptimal amounts of protective antigen. Vaccine 2008; 26(38): 49274939, https://doi.org/10.1016/j.vaccine.2008.07.015.

60. Giorno R., Mallozzi M., Bozue J., Moody K.S.,
Slack A., Quu D., Wang R., Friedlander A., Welkos S., Driks A. Localization and assembly of proteins comprising the outer structures of the Bacillus anthracis spore. Microbiology 2009; 155: 1133-1145, https://doi.org/10.1099/mic.0.023333-0.

61. Ramirez-Peralta A., Zhang P.F., Li Y.Q., Setlow P. Effects of sporulation conditions on the germination and germination protein levels of Bacillus subtilis spores. Appl Environ Microbiol 2012; 78(8): 2689-2697, https://doi. org/10.1128/aem.07908-11.

62. Imamura D., Kuwana R., Takamatsu H., Watabe K. Proteins involved in formation of the outermost layer of Bacillus subtilis spores. J Bacteriol 2011; 193(16): 4075-4080, https:// doi.org/10.1128/jb.05310-11.

63. Terry C., Jiang S., Radford D.S., Wan Q., Tzokov S., Moir A., Bullough P.A. Molecular tiling on the surface of a bacterial spore - the exosporium of the Bacillus anthracis/ cereus/thuringiensis group. Mol Microbiol 2017; 104(4): 539552, https://doi.org/10.1111/mmi.13650.

64. Barra-Carrasco J., Olguin-Araneda V., PlazaGarrido A., Miranda-Cardenas C., Cofré-Araneda G., Pizarro-Guajardo M., Sarker M.R., Paredes-Sabja D. The Clostridium difficile exosporium cysteine (CdeC)-rich protein is required for exosporium morphogenesis and coat assembly. J Bacteriol 2013; 195(17): 3863-3875, https://doi. org/10.1128/jb.00369-13.

65. Díaz-González F., Milano M., Olguin-Araneda V., Pizarro-Cerda J., Castro-Cordova P., Tzeng S.C., Maier C.S., Sarker M.R., Paredes-Sabja D. Protein composition of the outermost exosporium-like layer of Clostridium difficile 630 spores. J Proteomics 2015; 123: 1-13, https://doi. org/10.1016/j.jprot.2015.03.035.

66. McPherson S.A., Li M., Kearney J.F., Turnbough C.L. Jr. ExsB, an unusually highly phosphorylated protein required for the stable attachment of the exosporium of Bacillus anthracis. Mol Microbiol 2010; 76(6): 1527-1538, https://doi.org/10.1111/ j.1365-2958.2010.07182.x.

67. Rodenburg C.M., McPherson S.A., Turnbough C.L. Jr., Dokland T. Cryo-EM analysis of the organization of BclA and BxpB in the Bacillus anthracis exosporium. J Struct Biol 2014; 186(1): 181-187, https://doi.org/10.1016/j.jsb.2014.02.018.

68. Ehling-Schulz M., Lereclus D., Koehler T.M. The Bacillus cereus Group: Bacillus species with pathogenic potential. Microbiol Spectr 2019; 7(3), https://doi.org/10.1128/ microbiolspec.gpp3-0032-2018.

69. Pizarro-Guajardo M., Calderón-Romero P., CastroCórdova P., Mora-Uribe P., Paredes-Sabja D. Ultrastructural variability of the exosporium layer of Clostridium difficile spores. Appl Environ Microbiol 2016; 82(7): 2202-2209, https://doi.org/10.1128/aem.03410-15.

70. Pizarro-Guajardo M., Díaz-González F., ÁlvarezLobos M., Paredes-Sabja D. 622 characterization of chicken IgY specific to Clostridium difficile R20291 spores 623 and the effect of oral administration in mouse models of initiation and recurrent 624 disease. Front Cell Infect Microbiol 2017; 7: 365, https://doi.org/10.3389/fcimb.2017.00365.

71. Pizarro-Guajardo M., Olguín-Araneda V., BarraCarrasco J., Brito-Silva C., Sarker M.R., Paredes-Sabja D. Characterization of the collagen-like exosporium 634 protein, BclA1, of Clostridium difficile spores. Anaerobe 2014; 25: 1830, https://doi.org/10.1016/j.anaerobe.2013.11.003.

72. Pizarro-Guajardo M., Ravanal M.C., Paez M.D., Callegari E., Paredes-Sabja D. Identification of Clostridium difficile immunoreactive spore proteins of the epidemic strain 
R20291. Proteomics Clin App/ 2018; 12(5): e1700182, https:// doi.org/10.1002/prca.201700182.

73. Mora-Uribe P., Miranda-Cardenas C., CastroCordova P., Gil F., Calderón I., Fuentes J.A., Rodas P.I., Banawas S., Sarker M.R., Paredes-Sabja D. Characterization of the adherence of Clostridium difficile spores: the integrity of the outermost layer affects adherence properties of spores of the epidemic strain R20291 to components of the intestinal mucosa. Front Cell Infect Microbiol 2016; 6: 99, https://doi. org/10.3389/fcimb.2016.00099.

74. Boydston J.A., Yue L., Kearney J.F., Turnbough C.L. The ExsY protein is required for complete formation of the exosporium of Bacillus anthracis. J Bacteriol 2006; 188: 7440-7448.

75. Boydston J.A., Chen P., Steichen C.T., Turnbough C.L. Jr. Orientation within the exosporium and structural stability of the collagen-like glycoprotein BclA of Bacillus anthracis. J Bacteriol 2005; 187: 5310-5317, https:// doi.org/10.1128/jb.00639-06.

76. Brahmbhatt T.N., Janes B.K., Stibitz E.S., Darnell S.C., Sanz P., Rasmussen S.B., O'Brien A.D. Bacillus anthracis exosporium protein BclA affects spore germination, interaction with extracellular matrix proteins, and hydrophobicity. Infect Immun 2007; 75(11): 5233-5239, https://doi.org/10.1128/ iai.00660-07.

77. Brahmbhatt T.N., Darnell S.C., Carvalho H.M., Sanz P., Kang T.J., Bull R.L., Rasmussen S.B., Cross A.S., O'Brien A.D. Recombinant exosporium protein BclA of Bacillus anthracis is effective as a booster for mice primed with suboptimal amounts of protective antigen. Infect Immun 2007; 75(11): 5240-5247, https://doi.org/10.1128/iai.00884-07.

78. Bozue J.A., Welkos S., Cote C.K. The Bacillus anthracis exosporium: what's the big "hairy" deal? Microbiol Spectr 2015; 3(5), https://doi.org/10.1128/microbiolspec.tbs0021-2015.

79. Bozue J.A., Cote C.K., Moody K.L., Welkos S.L. Fully virulent Bacillus anthracis does not require the immunodominant protein BclA for pathogenesis. Infect Immun 2007; 75(1): 508-511, https://doi.org/10.1128/iai.01202-06.

80. Ball D.A., Taylor R., Todd S.J., Redmond C., CoutureTosi E., Sylvestre P. Structure of the exosporium and sublayers of spores of the Bacillus cereus family revealed by electron crystallography. Mol Microbiol 2008; 68(4): 947-958, https:// doi.org/10.1111/j.1365-2958.2008.06206.x.

81. Sylvestre P., Couture-Tosi E., Mock M. Polymorphism in the collagen-like region of the Bacillus anthracis BclA protein leads to variation in exosporium filament length. $J$ Bacteriol 2003; 185: 1555-1563, https://doi.org/10.1128/jb.185.5.15551563.2003.

82. Sylvestre P., Couture-Tosi E., Mock M. Contribution of ExsFA and ExsFB proteins to the localization of BclA on the spore surface and to the stability of the Bacillus anthracis exosporium. J Bacteriol 2005; 187(15): 5122-5128, https://doi. org/10.1128/jb.187.15.5122-5128.2005.

83. Wang C., Stanciu C., Ehrhardt C.J., Yadavalli V.K. Morphological and mechanical imaging of Bacillus cereus spore formation at the nanoscale. J Microsc 2015; 258(1): 4958, https://doi.org/10.1111/jmi.12214.

84. Weaver J., Kang T.J., Raines K.W., Cao G.L., Hibbs S., Tsai P., Baillie L., Rosen G.M., Cross A.S. Protective role of Bacillus anthracis exosporium in macrophage-mediated killing by nitric oxide. Infect Immun 2007; 75(8): 3894-3901, https:// doi.org/10.1128/iai.00283-07.
85. Todd S.J., Moir A.J.G., Johnson M.J., Moir A. Genes of Bacillus cereus and Bacillus anthracis encoding proteins of the exosporium. J Bacteriol 2003; 185: 3373-3378, https://doi. org/10.1128/jb.185.11.3373-3378.2003.

86. Wang Y., Jenkins S.A., Gu C., Shree A., MartinezMoczygemba M., Herold J., Botto M., Wetsel R.A., Xu Y. Bacillus anthracis spore surface protein BclA mediates complement factor $\mathrm{H}$ binding to spores and promotes spore persistence. PLoS Pathog 2016; 12(6): e1005678, https://doi. org/10.1371/journal.ppat.1005678.

87. Mehta A.S., Saile E., Zhong W., Buskas T., Carlson R., Kannenberg E., Reed Y., Quinn C.P., Boons G.J. Synthesis and antigenic analysis of the BclA glycoprotein oligosaccharide from the Bacillus anthracis exosporium. Chemistry 2006; 12(36): 9136-9149, https://doi.org/10.1002/chem.200601245.

88. Johnson M.J., Todd S.J., Ball D.A., Shepherd A.M., Sylvestre P., Moir A. ExsY and CotY are required for the correct assembly of the exosporium and spore coat of Bacillus cereus. J Bacteriol 2006; 188(22): 7905-7913, https://doi.org/10.1128/ jb.00997-06.

89. Thompson B.M., Stewart G.C. Targeting of the BclA and $\mathrm{BclB}$ proteins to the Bacillus anthracis spore surface. Mol Microbiol 2008; 70(2): 421-434, https://doi.org/10.1111/j.13652958.2008.06420.x.

90. Thompson B.M., Hsieh H.Y., Spreng K.A., Stewart G.C. The co-dependence of BxpB/ExsFA and BclA for proper incorporation into the exosporium of Bacillus anthracis. Mol Microbiol 2011; 79(3): 799-813, https://doi.org/10.1111/j.13652958.2010.07488.x.

91. Thompson B.M., Hoelscher B.C., Driks A., Stewart G.C. Assembly of the BclB glycoprotein into the exosporium and evidence for its role in the formation of the exosporium 'cap' structure in Bacillus anthracis. Mol Microbiol 2012; 86(5): 1073-1084, https://doi.org/10.1111/mmi.12042.

92. Steichen C., Kearney J.F., Turnbough C.L. Jr. Characterization of the exosporium basal layer protein BxpB of Bacillus anthracis. J Bacteriol 2005; 187(17): 5868-5876, https://doi.org/10.1128/jb.187.17.5868-5876.2005.

93. Severson K.M., Mallozzi M., Bozue J., Welkos S.L., Cote C.K., Knight K.L., Driks A. Roles of the Bacillus anthracis spore protein ExsK in exosporium maturation and germination. J Bacteriol 2009; 191(24): 7587-7596, https://doi.org/10.1128/ jb.01110-09.

94. Boone T.J., Mallozzi M., Nelson A., Thompson B., Khemmani M., Lehmann D., Dunkle A., Hoeprich P., Rasley A., Stewart G., Driks A. Coordinated assembly of the Bacillus anthracis coat and exosporium during bacterial spore outer layer formation. MBio 2018; 9(6): e01166-18, https://doi. org/10.1128/mbio.01166-18.

95. Lanzilli M., Donadio G., Addevico R., Saggese A., Cangiano G., Baccigalupi L., Christie G., Ricca E., Isticato R. The exosporium of Bacillus megaterium QM B1551 is permeable to the red fluorescence protein of the coral Discosoma sp. Front Microbiol 2016; 7: 1752, https://doi. org/10.3389/fmicb.2016.01752.

96. McKenney P.T., Driks A., Eskandarian H.A., Grabowski P., Guberman J., Wang K.H., Gitai Z., Eichenberger P. A distance-weighted interaction map reveals a previously uncharacterized layer of the Bacillus subtilis spore coat. Curr Biol 2010; 20(10): 934-938, https://doi. org/10.1016/j.cub.2010.03.060.

97. Shuster B., Khemmani M., Abe K., Huang X., Nakaya Y., Maryn N., Buttar S., Gonzalez A.N., Driks A., 
Sato T., Eichenberger P. Contributions of crust proteins to spore surface properties in Bacillus subtilis. Mol Microbiol 2019; 111(3): 825-843, https://doi.org/10.1111/mmi.14194.

98. Yan X., Gai Y., Liang L., Liu G., Tan H. A gene encoding alanine racemase is involved in spore germination in Bacillus thuringiensis. Arch Microbiol 2007; 187(5): 371-378, https:// doi.org/10.1007/s00203-006-0201-x.

99. Chesnokova O.N., McPherson S.A., Steichen C.T., Turnbough C.L. Jr. The spore-specific alanine racemase of Bacillus anthracis and its role in suppressing germination during spore development. J Bacteriol 2009; 191(4): 13031310, https://doi.org/10.1128/jb.01098-08.

100. Driks A. The Bacillus anthracis spore. Mol Aspects Med 2009; 30(6): 368-373, https://doi.org/10.1016/j. mam.2009.08.001.

101. Horii T., Notake S., Tamai K., Yanagisawa H. Bacillus cereus from blood cultures: virulence genes, antimicrobial susceptibility and risk factors for blood stream infection. FEMS Immunol Med Microbiol 2011; 63(2): 202-209, https://doi. org/10.1111/j.1574-695x.2011.00842.x.

102. Gauthier Y.P., Tournier J.N., Paucod J.C., Corre J.P., Mock M., Goossens P.L., Vidal D.R. Efficacy of a vaccine based on protective antigen and killed spores against experimental inhalational anthrax. Infect Immun 2009; 77(3): 1197-1207, https://doi.org/10.1128/iai.01217-08.

103. Ghose C., Eugenis I., Edwards A.N., Sun X., McBride S.M., Ho D.D. Immunogenicity and protective efficacy of Clostridium difficile spore proteins. Anaerobe 2016; 37: 8595, https://doi.org/10.1016/j.anaerobe.2015.12.001.

104. Vedantam G., Kochanowsky J., Lindsey J., Mallozzi M., Roxas J.L., Adamson C., Anwar F., Clark A., Claus-Walker R., Mansoor A., McQuade R., Monasky R.C., Ramamurthy S., Roxas B., Viswanathan V.K. An engineered synthetic biologic protects against Clostridium difficile infection. Front Microbiol 2018; 9: 2080, https://doi.org/10.3389/ fmicb.2018.02080.

105. Driks A., Eichenberger P. The spore coat. Microbiol Spectr 2016; 4(2): 1-22, https://doi.org/10.1128/microbiolspec. tbs-0023-2016.

106. Sorg J.A., Sonenshein A.L. Bile salts and glycine as cogerminants for Clostridium difficile spores. J Bacteriol 2008; 190(7): 2505-2512, https://doi.org/10.1128/jb.01765-07.

107. Dubberke E.R., Olsen M.A. Burden of Clostridium difficile on the healthcare system. Clin Infect Dis 2012; 55(Suppl 2): S88-S92, https://doi.org/10.1093/cid/cis335.

108. Driks A. Surface appendages of bacterial spores. Mol Microbiol 2007; 63(3) 623-625, https://doi.org/10.1111/j.13652958.2006.05564.x.

109. Edwards A.N., McBride S.M. Initiation of sporulation in Clostridium difficile: a twist on the classic model. FEMS Microbiol Lett 2014; 358(2): 110-118, https://doi. org/10.1111/1574-6968.12499.

110. Oliva C.R., Swiecki M.K., Griguer C.E., Lisanby M.W., Bullard D.C., Turnbough C.L. Jr., Kearney J.F. The integrin Mac-1 (CR3) mediates internalization and directs Bacillus anthracis spores into professional phagocytes. Proc Natl Acad Sci U S A 2008; 105(4): 1261-1266, https://doi.org/10.1073/ pnas.0709321105.

111. Tournier J.N., Ulrich R.G., Quesnel-Hellmann A., Mohamadzadeh M., Stiles B.G. Anthrax, toxins and vaccines: a 125-year journey targeting Bacillus anthracis. Expert Rev Anti-Infect Ther 2009; 7(2): 219-236, https://doi. org/10.1586/14787210.7.2.219.
112. Perego M., Hoch J.A. Commingling regulatory systems following acquisition of virulence plasmids by Bacillus anthracis. Trends Microbiol 2008; 16(5): 215-221, https://doi. org/10.1016/j.tim.2008.01.010.

113. Basoli F., Giannitelli S.M., Gori M., Mozetic P., Bonfanti A., Trombetta M., Rainer A. Biomechanical characterization at the cell scale: present and prospects. Front Physio/ 2018; 9: 1449, https://doi.org/10.3389/fphys.2018.01449.

114. Yoo L., Reed J., Shin A., Demer J.L. Atomic force microscopy determination of young's modulus of bovine extraocular tendon fiber bundles. J Biomech 2014; 47(8): 18991903, https://doi.org/10.1016/j.jbiomech.2014.02.011.

115. Alsteens D., Müller D.J., Dufrêne Y.F. Multiparametric atomic force microscopy imaging of biomolecular and cellular systems. Acc Chem Res 2017; 50(4): 924-931, https://doi. org/10.1021/acs.accounts.6b00638.

116. Bolshakova A.V., Kiselyova O.I., Yaminsky I.V. Microbial surfaces investigated using atomic force microscopy. Biotechnol Prog 2004; 20(6): 1615-1622, https://doi. org/10.1021/bp049742c

117. Prats-Mateu B., Gierlinger N. Tip in-light on: advantages, challenges, and applications of combining AFM and Raman microscopy on biological samples. Microsc Res Tech 2017; 80(1): 30-40, https://doi.org/10.1002/jemt.22744.

118. Gavara N. A beginner's guide to atomic force microscopy probing for cell mechanics. Microsc Res Tech 2017; 80(1): 75-84, https://doi.org/10.1002/jemt.22776.

119. Scheuring S., Dufrêne Y.F. Atomic force microscopy: probing the spatial organization, interactions and elasticity of microbial cell envelopes at molecular resolution. Mol Microbiol 2010; 75(6): 1327-1336, https://doi.org/10.1111/j.13652958.2010.07064.x.

120. Müller D.J., Dufrêne Y.F. Atomic force microscopy as a multifunctional molecular toolbox in nanobiotechnology. Nat Nanotechnol 2008; 3(5): 261-269, https://doi.org/10.1038/ nnano.2008.100.

121. Xiao J., Dufrêne Y.F. Optical and force nanoscopy in microbiology. Nat Microbiol 2016; 1(11): 16186, https://doi. org/10.1038/nmicrobiol.2016.186.

122. Gordon V.D., Wang L. Bacterial mechanosensing: the force will be with you, always. J Cell Sci 2019; 132(7): jcs227694, https://doi.org/10.1242/jcs.227694.

123. Morisaku T., Kido Y., Asai K., Yui H. Mechanical properties of the coat protein layer and cortex in single Bacillus subtilis spores studied with an atomic force microscope and laser-induced surface deformation microscope. Anal Sci 2019; 35(1): 45-48, https://doi.org/10.2116/analsci.18sdp02.

124. Iturri J., Toca-Herrera J.L. Characterization of cell scaffolds by atomic force microscopy. Polymers (Basel) 2017; 9(8): E383, https://doi.org/10.3390/polym9080383.

125. Zolock R.A., Li G., Bleckmann C., Burggraf L.W., Fuller D.C. Atomic force microscopy of Bacillus spore surface morphology. Micron 2006; 37(4): 363-369, https://doi. org/10.1016/j.micron.2005.11.006.

126. Dufrêne Y.F. Atomic force microscopy in microbiology: new structural and functional insights into the microbial cell surface. MBio 2014; 5(4): e01363-14, https://doi.org/10.1128/ mbio.01363-14.

127. Chiorcea-Paquim A.M., Eritja R., Oliveira-Brett A.M. Electrochemical and AFM characterization of G-Quadruplex electrochemical biosensors and applications. J Nucleic Acids 2018; 2018: 5307106, https://doi.org/10.1155/2018/ 5307106. 
128. Benitez R., Toca-Herrera J.L. Looking at cell mechanics with atomic force microscopy: experiment and theory. Microsc Res Tech 2014; 77(11): 947-958, https://doi. org/10.1002/jemt.22419.

129. Fisher N., Hanna P. Characterization of Bacillus anthracis germinant receptors in vitro. J Bacteriol 2005; 187(23): 8055-8062, https://doi.org/10.1128/jb.187.23.80558062.2005 .

130. Xing Y., Li A., Felker D.L., Burggraf L.W. Nanoscale structural and mechanical analysis of Bacillus anthracis spores inactivated with rapid dry heating. Appl Environ Microbiol 2014; 80(5): 1739-1749, https://doi.org/10.1128/aem.03483-13.

131. Cote C.K., Bozue J., Moody K.L., DiMezzo T.L., Chapman C.E., Welkos S.L. Analysis of a novel spore antigen in Bacillus anthracis that contributes to spore opsonization. Microbiology 2008; 154(Pt 2): 619-632, https://doi.org/10.1099/ mic.0.2007/008292-0.

132. Fox A., Stewart G.C., Wallera L.N., Fox K.F., Harley W.M., Price R.L. Carbohydrates and glycoproteins of Bacillus anthracis and related bacilli: targets for biodetection. J Microbiol Methods 2003; 54(2): 143-152, https://doi. org/10.1016/s0167-7012(03)00095-2.

133. Chan J.W., Esposito A.P., Talley C.E., Hollars C.W., Lane S.M., Huser T. Reagentless identification of single bacterial spores in aqueous solution by confocal laser tweezers Raman spectroscopy. Anal Chem 2004; 76(3): 599603, https://doi.org/10.1021/ac0350155.

134. Evanoff D.D. Jr., Heckel J., Caldwell T.P., Christensen K.A., Chumanov G. Monitoring DPA release from a single germinating Bacillus subtilis endospore via surfaceenhanced Raman scattering microscopy. J Am Chem Soc 2006; 128(39): 12618-12619, https://doi.org/10.1021/ja0642717.

135. Daniels J.K., Caldwell T.P., Christensen K.A., Chumanov G. Monitoring the kinetics of Bacillus subtilis endospore germination via surface-enhanced Raman scattering spectroscopy. Anal Chem 2006; 78(5): 1724-1729, https://doi.org/10.1021/ac052009v.

136. Huang S.S., Chen D., Pelczar P.L., Vepachedu V.R., Setlow P., Li Y.Q. Levels of Ca2+-dipicolinic acid in individual Bacillus spores determined using microfluidic Raman tweezers. J Bacteriol 2007; 189(13): 4681-4687, https://doi.org/10.1128/ jb.00282-07.

137. Wang S., Doona C.J., Setlow P., Li Y.Q. Use of Raman spectroscopy and phase-contrast microscopy to characterize cold atmospheric plasma inactivation of individual bacterial spores. Appl Environ Microbiol 2016; 82(19): 57755784, https://doi.org/10.1128/aem.01669-16.

138. Boitor R., Sinjab F., Strohbuecker S., Sottile V., Notingher I. Towards quantitative molecular mapping of cells by Raman microscopy: using AFM for decoupling molecular concentration and cell topography. Faraday Discuss 2016; 187 : 199-212, https://doi.org/10.1039/c5fd00172b.

139. Jung H., Kim D.B., Gweon B., Moon S.Y., Choe W. Enhanced inactivation of bacterial spores by atmospheric pressure plasma with catalyst TiO2. Appl Catal B-Environ 2010; 93(3-4): 212-216, hhttps://doi.org/10.1016/j.pcatb.2009.09.031.

140. Shintani $H$. Inactivation of bacterial spore, endotoxin, lipid $A$, normal prion and abnormal prion by exposures to several sorts of gases plasma. Biocontrol Sci 2016; 21(1): 1-12, https://doi.org/10.4265/bio.21.1.

141. López M., Calvo T., Prieto M., Múgica-Vidal R., MuroFraguas I., Alba-Elías F., Alvarez-Ordóñez A. A review on non-thermal atmospheric plasma for food preservation: mode of action, determinants of effectiveness, and applications. Front Microbiol 2019; 10: 622, https://doi.org/10.3389/ fmicb.2019.00622.

142. Hertwig C., Steins V., Reineke K., Rademacher A., Klocke M., Rauh C., Schlüter O. Impact of surface structure and feed gas composition on Bacillus subtilis endospore inactivation during direct plasma treatment. Front Microbiol 2015; 6: 774, https://doi.org/10.3389/fmicb.2015.00774.

143. Schlüter O., Ehlbeck J., Hertel C., Habermeyer M., Roth A., Engel K.H., Holzhauser T., Knorr D., Eisenbrand G. Opinion on the use of plasma processes for treatment of foods. Mol Nutr Food Res 2013; 57(5): 920-927, https://doi. org/10.1002/mnfr.201300039.

144. van Bokhorst-van de Veen H., Xie H., Esveld E., Abee T., Mastwijk H., Nierop Groot M. Inactivation of chemical and heat-resistant spores of Bacillus and Geobacillus by nitrogen cold atmospheric plasma evokes distinct changes in morphology and integrity of spores. Food Microbiol 2015; 45(Pt A): 26-33, https://doi.org/10.1016/j.fm.2014.03.018.

145. Reineke K., Langer K., Hertwig C., Ehlbeck J., Schlüter $O$. The impact of different process gas compositions on the inactivation effect of an atmospheric pressure plasma jet on Bacillus spores. Innov Food Sci Emerg Technol 2015; 30: 112-118, https://doi.org/10.1016/j.ifset.2015.03.019.

146. Klämpfl T.G., Isbary G., Shimizu T., Li Y.F., Zimmermann J.L., Stolz W., Schlegel J., Morfill G.E., Schmidt H.U. Cold atmospheric air plasma sterilization against spores and other microorganisms of clinical interest. Appl Environ Microbiol 2012; 78(15): 5077-5082, https://doi. org/10.1128/aem.00583-12.

147. Takamatsu T., Uehara K., Sasaki Y., Hidekazu M., Matsumura Y., Iwasawa A., Ito N., Kohno M., Azuma T., Okino A. Microbial inactivation in the liquid phase induced by multigas plasma jet. PLoS One 2015; 10(7): e0132381, https:// doi.org/10.1371/journal.pone.0132381.

148. Tseng S., Abramzon N., Jackson J.O., Lin W.J. Gas discharge plasmas are effective in inactivating Bacillus and Clostridium spores. Appl Microbiol Biotechnol 2012; 93(6): 2563-2570, https://doi.org/10.1007/s00253-011-3661-0.

149. Ercan U.K., Smith J., Ji H.F., Brooks A.D., Joshi S.G. Chemical changes in nonthermal plasma-treated $\mathrm{N}$-acetylcysteine (NAC) solution and their contribution to bacterial inactivation. Sci Rep 2016; 6: 20365, https://doi. org/10.1038/srep20365.

150. Ricca E., Cutting S.M. Emerging applications of bacterial spores in nanobiotechnology. J Nanobiotechnology 2003; 1(1): 6, https://doi.org/10.1186/1477-3155-1-6.

151. Minton N.P. Clostridia in cancer therapy. Nat Rev Microbiol 2003; 1(3): 237-242, https://doi.org/10.1038/ nrmicro777.

152. Bengtsson-Palme J., Kristiansson E., Larsson D.G.J. Environmental factors influencing the development and spread of antibiotic resistance. FEMS Microbiol Rev 2018; 42(1), https://doi.org/10.1093/femsre/fux053.

153. Uyen N.Q., Hong H.A., Cutting S.M. Enhanced immunisation and expression strategies using bacterial spores as heat-stable vaccine delivery vehicles. Vaccine 2007; 25(2): 356-365, https://doi.org/10.1016/j.vaccine.2006.07.025.

154. Roberts N.J., Zhang L., Janku F., Collins A., Bai R.Y., Staedtke V., Rusk A.W., Tung D., Miller M., Roix J., Khanna K.V., Murthy R., Benjamin R.S., Helgason T., Szvalb A.D., Bird J.E., Roy-Chowdhuri S., Zhang H.H., Qiao Y., Karim B., McDaniel J., Elpiner A., Sahora A., Lachowicz J., 


\section{REVIEWS}

Phillips B., Turner A., Klein M.K., Post G., Diaz L.A. Jr., Riggins G.J., Papadopoulos N., Kinzler K.W., Vogelstein B., Bettegowda C., Huso D.L., Varterasian M., Saha S., Zhou S. Intratumoral injection of Clostridium novyi-NT spores induces antitumor responses. Sci Transl Med 2014; 6(249): 249ra111, https://doi.org/10.1126/scitransImed.3008982.

155. Heap J.T., Theys J., Ehsaan M., Kubiak A.M., Dubois L., Paesmans K., Van Mellaert L., Knox R., Kuehne S.A., Lambin P., Minton N.P. Spores of Clostridium engineered for clinical efficacy and safety cause regression and cure of tumors in vivo. Oncotarget 2014; 5(7): 1761-1769, https://doi.org/10.18632/oncotarget.1761.

156. Sibley L., Reljic R., Radford D.S., Huang J.M., Hong H.A., Cranenburgh R.M., Cutting S.M. Recombinant Bacillus subtilis spores expressing MPT64 evaluated as a vaccine against tuberculosis in the murine model. FEMS Microbiol Lett 2014; 358(2): 170-179, https://doi. org/10.1111/1574-6968.12525.

157. Das K., Thomas T., Garnica O., Dhandayuthapani S. Recombinant Bacillus subtilis spores for the delivery of Mycobacterium tuberculosis Ag85B-CFP10 secretory antigens. Tuberculosis (Edinb) 2016; 101S: S18-S27, https://doi. org/10.1016/j.tube.2016.09.016.
158. Duc le H., Hong H.A., Fairweather N., Ricca E., Cutting S.M. Bacterial spores as vaccine vehicles. Infect Immun 2003; 71(5): 2810-2818, https://doi.org/10.1128/ iai.71.5.2810-2818.2003.

159. Farjadian F., Moghoofei M., Mirkiani S., Ghasemi A., Rabiee N., Hadifar S., Beyzavi A., Karimi M., Hamblin M.R. Bacterial components as naturally inspired nano-carriers for drug/gene delivery and immunization: set the bugs to work? Biotechnol Adv 2018; 36(4): 968-985, https://doi.org/10.1016/j. biotechadv.2018.02.016.

160. Paul C., Filippidou S., Jamil I., Kooli W., House G.L., Estoppey A., Hayoz M., Junier T., Palmieri F., Wunderlin T., Lehmann A., Bindschedler S., Vennemann T., Chain P.S.G., Junier P. Bacterial spores, from ecology to biotechnology. Adv Appl Microbiol 2019; 106: 79-111, https://doi.org/10.1016/ bs.aambs.2018.10.002.

161. Shoemaker W.R., Lennon J.T. Evolution with a seed bank: the population genetic consequences of microbial dormancy. Evol Appl 2018; 11(1): 60-75, https://doi. org/10.1111/eva.12557.

162. Tetz G., Tetz V. Introducing the sporobiota and sporobiome. Gut Pathog 2017; 9: 38, https://doi.org/10.1186/ s13099-017-0187-8. 